\title{
Renal tubular injury induced by glyphosate combined with hard water: the role of cytosolic phospholipase $\mathbf{A 2}$
}

\author{
Ruojing Wang ${ }^{1 \#}$, Jing Chen ${ }^{2 \#}$, Fan Ding ${ }^{1}$, Lin Zhang ${ }^{1}$, Xuan Wu ${ }^{1}$, Yi Wan ${ }^{3}$, Jianying Hu ${ }^{3}$, Xiaoyan Zhang ${ }^{2}$, \\ Qing $\mathbf{W u}{ }^{1}$
}

${ }^{1}$ School of Public Health and Key Laboratory of Public Health Safety of the Ministry of Education, Fudan University, Shanghai, China; ${ }^{2}$ Department of Nephrology, Zhongshan Hospital, Fudan University, Shanghai, China; ${ }^{3}$ Laboratory for Earth Surface Processes, College of Urban and Environmental Sciences, Peking University, Beijing, China

Contributions: (I) Conception and design: Q Wu, Y Wan, J Hu; (II) Administrative support: J Hu, X Zhang, Q Wu; (III) Provision of study materials or patients: J Chen, Q Wu; (IV) Collection and assembly of data: R Wang, J Chen, F Ding, L Zhang, X Wu, Q Wu; (V) Data analysis and interpretation: R Wang, J Chen, Q Wu; (VI) Manuscript writing: All authors; (VII) Final approval of manuscript: All authors.

"These authors contributed equally to this work.

Correspondence to: Qing Wu. School of Public Health, Fudan University, P.O. Box 288, 130 Dong An Road, Shanghai, China. Email: qingwu@fudan.edu.cn; Xiaoyan Zhang. Department of Nephrology, Zhongshan Hospital, Fudan University, No. 180 Fenglin Road, Shanghai, China. Email: zhang.xiaoyan@zs-hospital.sh.cn.

Background: The combined effects of glyphosate and hard water on chronic kidney disease of unknown etiology $(\mathrm{CDKu})$ have attracted much interest, but the mechanisms remain unknown. Cytoplasmic phospholipase $\mathrm{A}_{2}\left(\mathrm{cPLA}_{2}\right)$ plays a key role in the acute and chronic inflammatory reactions. This study explored the effect of glyphosate combined with hard water on renal tubules and the possible targets and mechanisms involved.

Methods: In vivo experiments were conducted to investigate the synergistic effects and potential mechanisms of glyphosate and hard water on renal tubular injury in mice.

Results: Administration of glyphosate in mice resulted in elevated levels of $\beta 2$-microglobulin $\left(\beta_{2}-M G\right)$, albumin (ALB), and serum creatinine (SCr) compared to control mice. This increase was more pronounce when glyphosate was combined with hard water. In the glyphosate-treated mice, small areas of the kidney revealed fibroblast proliferation and vacuolar degeneration, particularly at the higher dose of $400 \mathrm{mg} / \mathrm{kg}$ glyphosate. However, the combination of glyphosate and hard water induced an even greater degree of pathological changes in the kidney. Immunofluorescence and western blot analyses showed that glyphosate and hard water had a coordinated effect on calcium ions $\left(\mathrm{Ca}^{2+}\right)$-activated phospholipase $\mathrm{A}_{2}$ and the activation may play a key role in inflammation and renal tubular injury. Exposure to glyphosate alone or glyphosate plus hard water increased the levels of oxidative stress markers and inflammatory biomarkers, namely, thromboxane $\mathrm{A}_{2}\left(\mathrm{TX}-\mathrm{A}_{2}\right)$, leukotriene $\mathrm{B}_{4}\left(\mathrm{LTB}_{4}\right)$, prostaglandin $\mathrm{E}_{2}\left(\mathrm{PGE}_{2}\right)$, nitric oxide synthase (NOS), and nitric oxide (NO). Parameters of oxidative stress, including the levels of superoxide dismutase (SOD) and glutathione peroxidase (GSH-Px) were decreased. Further analysis showed that the levels of these biomarkers were significantly different between the mice treated with glyphosate plus hard water and the mice treated with glyphosate alone.

Conclusions: These findings suggested that hard water combined with glyphosate can induce renal tubular injury in mice, and this may involve mitogen-activated protein kinases (MAPK)/cytosolic phospholipase $\mathrm{A}_{2}$ $\left(\mathrm{cPLA}_{2}\right)$ /arachidonic acid (AA) and its downstream factors.

Keywords: Glyphosate; hard water; renal tubule; calcium sensitive receptor; cytosolic phospholipase $\mathrm{A}_{2}$

Submitted Oct 16, 2020. Accepted for publication Dec 26, 2020.

doi: 10.21037/atm-20-7739

View this article at: http://dx.doi.org/10.21037/atm-20-7739 


\section{Introduction}

The recent emergence of chronic kidney disease of unknown etiology (CKDu) has become a global public health crisis. In India and Egypt, the prevalence of CKDu is $16 \%$ and $27 \%$, respectively $(1,2)$. According to the available data, the disease now affects approximately 2.5 million people worldwide (3). Although the disease progresses slowly, it often develops into end-stage renal disease, leading to the premature death of patients. Therefore, it is particularly important to explore the etiology of CKDu. Several studies have shown that exposure to glyphosate, hard water, and other environmental factors are considered key etiological factors for the prevalence of $\mathrm{CKDu}(4,5)$.

Glyphosate has been widely used as a high-efficiency, low-toxicity, broad-spectrum herbicide in the world. The rate of glyphosate application has escalated dramatically since its introduction in the 1970s. Today, a reported one million tons are used annually. Due to the promotion of genetically engineered crops, the agricultural use of glyphosates has increased considerably. As a result, its concentrations in aquatic environments have risen markedly, along with increased detection of both glyphosate and its major metabolite in the human body (6-8). Animal and epidemiology studies have revealed that glyphosate has a high tendency to persist and accumulate in the body. Even low concentrations of glyphosate in the human body can lead to liver and renal dysfunction $(9,10)$. Our previous studies demonstrated that glyphosateinduced nephrotoxicity was dependent on the activation of N-methyl-D-aspartate receptors (NMDARs) expressed in the proximal tubular epithelium. This resulted in the elevation of cytoplasmic calcium ions $\left(\mathrm{Ca}^{2+}\right)$ and oxidative damage (11).

Hard water is another environmental factor intricately linked to the incidence of CKDu in endemic areas. Hard water is widely distributed in Asia, and can measure more than $250 \mathrm{mg} / \mathrm{L}$ (12). Continuous intake of high $\mathrm{Ca}^{2+}$ will increase intestinal $\mathrm{Ca}^{2+}$ absorption. To normalize blood calcium levels, the body will send hormonal signals to increase renal calcium reabsorption. The calcium-sensing receptor (CaSR) plays an important role in this process. Ferrè and colleagues (13) demonstrated that increased levels of plasma of $\mathrm{Ca}^{2+}$ and magnesium $\left(\mathrm{Mg}^{2+}\right)$ binds and activates the CaSR in proximal tubules. This stimulates both the influx and release of $\mathrm{Ca}^{2+}$ from intracellular storage sites, leading to reduced parathyroid hormone secretion and calcium resorption in the renal tubule. While hard water may be involved in renal injury through the above mechanisms, to date, there has been insufficient research in this area. In addition, the role of the CaSR in renal tubular injury induced by hard water and glyphosate is still unclear. Therefore, exploring the effect of glyphosate combined with hard water on renal tubular injury and the possible mechanisms may lead to improved understanding of the risk factors leading to $\mathrm{CKDu}$, and hence provide support for reducing the use of glyphosates, hence reducing the incidence of CKDu.

Cytosolic phospholipase $\mathrm{A}_{2}\left(\mathrm{cPLA}_{2}\right)$ is a highly conserved lipid-modifying enzyme. It cleaves arachidonic acid (AA) from glycerophospholipids by catalyzing the hydrolysis of the bond at the sn-2 position $(14,15)$. Elevated cytosolic $\mathrm{Ca}^{2+}$ and phosphorylated mitogen-activated protein kinase (MAPK) are necessary for ${ }^{2} \mathrm{PLA}_{2}$ to produce free AA, which is then oxidized by lipoxygenase and cyclooxygenase to produce proinflammatory eicosanoids, such as prostaglandins (PGs) and leukotrienes (LTs) (16-18). Previous evidence have implicated these eicosanoids in a host of inflammatory disorders, and thus $\mathrm{cPLA}_{2}$ may play an important role in the development of inflammatory diseases (19-21). Furthermore, our previous study (11) demonstrated that oral exposure of glyphosate at a dose of $400 \mathrm{mg} / \mathrm{kg}$ in mice resulted in intracellular calcium $\left(\left[\mathrm{Ca}^{2+}\right]_{\mathrm{i}}\right)$ overload and overproduction of reactive oxygen species (ROS). This suggested that $\mathrm{CPLA}_{2}$ may be involved in renal tubular damage induced by glyphosate. Further studies are warranted to determine the specific mechanisms

In this study, we investigated the effects of glyphosate and hard water on the renal tubule and examined the potential role of $\mathrm{CPLA}_{2}$ in this process. We present the following article in accordance with the ARRIVE reporting checklist (available at http://dx.doi.org/10.21037/atm-207739).

\section{Methods}

\section{Primary materials}

Roundup (41\% isopropylamine salt) was purchased from Monsanto (St, Louis, MO, USA). Anhydrous calcium chloride and magnesium chloride hexahydrate (analytical reagent grade) were obtained from Sinopharm Chemical Reagent Co., Ltd.

\section{Animals}

Animal experiments were approved by the Fudan University Animal Care and Use Committee, in accordance with the 
Guide for the Care and Use of Laboratory Animals issued by the Ministry of Health of the People's Republic of China.

Male Institute of Cancer Research (ICR) mice, 6 weeks old and weighing 28-30 grams, were acquired from Shanghai SLAC Laboratory Animal Co., Ltd. The animals were housed under a 12 -h light-dark cycle at $25^{\circ} \mathrm{C}$ and humidity of $45 \% \pm 5 \%$ with free access to standard food and distilled water. All mice were adapted in the housing for 1 week prior to treatment. After 7 weeks of age, mice were divided randomly into six groups (8 animals per group): control group, hard water group, $100 \mathrm{mg} / \mathrm{kg}$ glyphosate group, $100 \mathrm{mg} / \mathrm{kg}$ glyphosate plus hard water group, $400 \mathrm{mg} / \mathrm{kg}$ glyphosate group, and $400 \mathrm{mg} / \mathrm{kg}$ glyphosate plus hard water group. Mice in the glyphosate groups were administered glyphosate at a daily dose of 100 or $400 \mathrm{mg} / \mathrm{kg}$ via oral gavage for 90 days. Mice in glyphosate plus hard water group were administered glyphosate at a daily dose of 100 or $400 \mathrm{mg} / \mathrm{kg}$ and $250 \mathrm{mg} / \mathrm{L}$ hard water via oral gavage for 90 days. Mice in the control group were administered distilled water via oral gavage for 90 days. For the duration of the experiment, all mice were given free access to hard water $(250 \mathrm{mg} / \mathrm{L})$ or distilled water. For administration, all mice were given to the mice once per day in a volume of $0.1 \mathrm{~mL} / 10 \mathrm{~g}$ of body weight. The body weight of all mice was measured daily. Urine was collected using metabolic cages at 30 and 90 days. At the end of the exposure period, mice were sacrificed under anesthesia with an intraperitoneal injection of pentobarbital sodium. Blood samples and renal tissues were collected. The left kidney was harvested and stored at $-80{ }^{\circ} \mathrm{C}$ for enzyme-linked immunosorbent assay (ELISA) and western blot analysis. The right kidney was fixed in $4 \%$ paraformaldehyde solution and embedded in paraffin blocks.

\section{Measurement of cytokine expression in the serum and urine}

Urine and serum were gathered through deposition and centrifugation, and then stored at $-80{ }^{\circ} \mathrm{C}$. $\beta_{2}$-microglobulin $\left(\beta_{2}-\mathrm{MG}\right)$, albumin (ALB), and serum creatinine (SCr) levels were measured using an ELISA kit in accordance with the manufacturer's instructions (Yuanmin Biotechnology Co., Ltd, Shanghai, China). The absorbance at $450 \mathrm{~nm}$ (OD450) was detected using a microplate reader. Samples were assayed in triplicate and the concentrations of $\beta_{2}-\mathrm{MG}, \mathrm{ALB}$, and $\mathrm{SCr}$ were calculated using the averaged absorbance readings and a standard curve.

\section{Periodic acid-Schiff staining and immunobistochemistry}

The kidney tissues were fixed in a $4 \%$ paraformaldehyde buffer. Tissue samples were cleared in xylene and embedded in paraffin followed by dehydration in graded alcohols. Sections of the kidney paraffin blocks $(4 \mu \mathrm{m})$ were stained with periodic acid-Schiff (PAS) stain and visualized with a microscope (Olympus, Tokyo, Japan). For each sample, ten random non-overlapping fields of view (400× magnification) were examined. The area of kidney injury was quantified using the Image J software.

Immunohistochemistry was used to detect $\mathrm{N}$-methyl$\mathrm{d}$-aspartate receptor 1 (NMDAR1) expression. Tissue slides were immersed in sodium citrate $(\mathrm{pH}$ 6), followed by blocking in $10 \%$ goat serum. After several washes, sections were incubated with a rabbit monoclonal antiNMDAR1 primary antibody (Shanghai Yuanmin Biotechnology Co., Ltd, 1:10) at $4{ }^{\circ} \mathrm{C}$ overnight. Samples were then incubated with an anti-rabbit horseradish peroxidase-conjugated secondary antibody for 50 minutes at room temperature. Following this, slides were stained with 3,3'-diaminobenzidine (1:50) for 5 minutes and counterstained with hematoxylin for 3 minutes. Images were observed under a microscope at $200 \times$ magnification. Cells staining yellow was considered as positive NMDAR1 expression.

\section{Electron microscopic examination}

Small pieces of renal cortex tissue (approximately $1 \mathrm{~mm}^{3}$ ) were immersed in $0.1 \mathrm{M}$ sodium phosphate buffer containing $2.5 \%$ glutaraldehyde, and post-fixed in $1 \%$ osmium tetroxide solution. The tissue specimens were dehydrated in a graded ethanol water series and embedded in Agar-100 resin. Ultrathin sections were doubly stained with uranyl acetate and lead citrate solutions and observed using a HT7700 transmission electron microscope (Hitachi, Japan).

\section{Terminal deoxynucleotidyl transferase dUTP nick end labeling (TUNEL) analysis of apoptosis}

Apoptosis was measured by using terminal deoxynucleotidyl transferase dUTP nick end labeling (TUNEL) analysis according to the manufacturer's instructions (Shanghai Yuanmin Biotechnology Co., Ltd). The kidney samples were fixed in formalin, processed, and embedded with paraffin. After deparaffinization and rehydration, the 
sections were permeabilized with proteinase $\mathrm{K}$ solution, and subsequently incubated with the TUNEL reaction mixture at $37{ }^{\circ} \mathrm{C}$ for 2 hours in a humidified chamber. The reaction was halted with 4'-6-Diamidino-2-phenylindole (DAPI). Finally, fluorescence images were analyzed using an Olympus microscope at 200x magnification. Five different fields of view were examined for each kidney section. Cells with green fluorescence were interpreted as TUNELpositive.

\section{Immunobistofluorescence analysis for CaSR}

Renal sections were fixed with a $4 \%$ paraformaldehyde solution for $4-6$ hours at $4{ }^{\circ} \mathrm{C}$, then transferred into a $30 \%$ sucrose solution overnight. Samples were embedded in optimal cutting temperature (OCT) compound, cut into serial $8 \mu \mathrm{m}$ thick sections, placed on glass slides, and fixed in acetone for 10 minutes. Subsequently, slides were washed three times in phosphate-buffered saline (PBS) and blocked with $5 \%$ goat serum for 30 minutes at room temperature, followed by overnight incubation at $4{ }^{\circ} \mathrm{C}$ with primary antibodies against the CaSR (1:100, Proteintech Group). Slides were then incubated with Alexa Fluor 488-conjugated goat anti-rabbit antibody $(1: 1,000$, CST) for 1 hour at room temperature in the dark. After treatment with DAPI (Beyotime, Shanghai, China), the sections were washed an additional three times. Slides were then visualized with a laser confocal microscope (Olympus, Tokyo, Japan). The $\mathrm{CaSR}$ and nucleus were stained green and blue, respectively.

\section{Flow cytometric analysis of renal tissue}

Tissue samples $(30 \mathrm{~g})$ were minced and digested with type II collagenase. Isolated cells were collected and washed with $1 \mathrm{~mL}$ PBS. The supernatant was removed after centrifugation and re-suspended in $0.1 \mathrm{~mL}$ PBS. The suspension was then transferred to $1.5 \mathrm{~mL}$ centrifuge tubes and blocked with $3 \%$ bovine serum albumin (BSA) for 30 minutes. Subsequently, $100 \mu \mathrm{L}$ of primary antibodies against CaSR (Cell Signaling) and phosphorylated cPLA (p-cLPA 2, Ser505, Cell Signaling) were added at a 1:100 dilution and incubated at $37^{\circ} \mathrm{C}$ for 2 hours. After washing, Alexa Fluor 488-conjugated goat anti-rabbit secondary antibody was added and incubated at room temperature for 30 minutes. The cells were washed twice, resuspended in the flow medium in the dark, and analyzed with flow cytometry (CytoFLEX, Beckman).

\section{Identifying the biomarkers of inflammation and oxidative stress in renal tissue}

Frozen kidney tissue samples were homogenized with PBS on ice and centrifuged at $4{ }^{\circ} \mathrm{C}$ for 10 minutes. The supernatants were collected and the levels of oxidative stress markers and inflammatory biomarkers [thromboxane $\mathrm{A}_{2}$ (TX-A $)$, leukotriene $\mathrm{B}_{4}\left(\mathrm{LTB}_{4}\right)$, prostaglandin $\mathrm{E}_{2}\left(\mathrm{PGE}_{2}\right)$, nitric oxide synthase (NOS), and nitric oxide (NO), superoxide dismutase (SOD) and glutathione peroxidase (GSH-Px) were measured using ELISA kits (Yuanmin Biotechnology Co., Ltd, Shanghai, China) according to the manufacturer's instructions.

\section{Western blot analysis}

Frozen kidney tissue samples $(30 \mathrm{mg})$ were homogenized in cold lysis buffer containing Phenylmethanesulfonyl fluoride (PMSF, Beyotime, Shanghai, China) for 90 seconds. After centrifugation for 10 minutes at $14,000 \mathrm{~g}$ at $4{ }^{\circ} \mathrm{C}$, the supernatant was collected. Protein concentration was detected using the bicinchoninic acid (BCA) protein assay kit (Beyotime, Shanghai, China). Equal amounts of protein were mixed with sample buffer and electrophoretically separated on a $5 \%$ to $12 \%$ sodium dodecyl sulfatepolyacrylamide gel electrophoresis (SDS-PAGE) gel. Samples were then transferred onto polyvinylidene fluoride (PVDF) membranes by wet electrophoresis $(350 \mathrm{~mA}$ for 75 minutes). The membrane was then blocked with 5\% skimmed milk powder for 2 hours at room temperature followed by overnight incubation at $4{ }^{\circ} \mathrm{C}$ with primary antibodies against total $\mathrm{cPLA}_{2}\left(\mathrm{t}-\mathrm{cPLA}_{2}, 1: 1,000\right.$, Cell

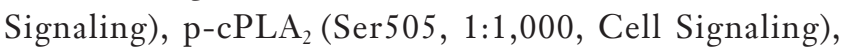
CaSR (1:1,000, Cell Signaling), and $\beta$-actin $(1: 5,000$, Sigma). After washing with TBST, the membranes were incubated with anti-mouse or anti-rabbit secondary antibody (1:2,000, Cell Signaling) for 2 hours at room temperature. Finally, visualization was performed using electrochemiluminescence (ECL) chemiluminescence solution and $\beta$-actin was used as an internal control.

\section{Statistical analysis}

The data showed normal distribution and were expressed as the means \pm standard deviation (SD) and analyzed using the SPSS version 22.0 software (IBM, Armonk, USA) and GraphPad Prism 7.00 (GraphPad Software Inc., San Diego, 
CA, USA). Mean comparison was determined using singlefactor analysis of variance (ANOVA) followed by Dunnett's multiple comparison tests. The interaction between glyphosate and hard water was analyzed by ANOVA. All experiments were repeated in triplicates and a $\mathrm{P}$ value of less than 0.05 was considered statistically significant.

\section{Results}

\section{General signs and renal function parameters}

Control mice maintained a stable weight, while mice exposed to glyphosate alone or in combination with hard water showed a slight decrease in body weight. However, there was no statistically significant differences in body weight gain among the various groups examined (Figure 1A). Glyphosate alone or in combination with hard water had no effect on the kidney weight or kidney weight index compared to control mice (Figure 1B). To evaluate the role of glyphosate and hard water in renal function, the levels of $\beta 2-M G$ and ALB in mice after 30 and 90 days of exposure were measured. As shown in the Figure $1 C$ and $D$, $\beta_{2}-M G$ and ALB levels in the glyphosate and glyphosate plus hard water groups were significantly higher than in the control mice. Further analysis showed that the levels of $\beta_{2}-M G$ and ALB in the $400 \mathrm{mg} / \mathrm{kg}$ glyphosate group were higher than those in the $100 \mathrm{mg} / \mathrm{kg}$ glyphosate group. Mice exposed to glyphosate plus hard water showed significantly higher levels of $\beta_{2}$-MG and ALB compared with mice treated with glyphosate alone. However, there was no statistical significance between mice treated with hard water alone and mice in the control group. Similar results were observed with SCr levels (Figure 1E), indicating that the combined effect of glyphosate and hard water was more remarkable than that of glyphosate alone.

\section{Synergistic effect of glyphosate and hard water on renal biomarkers}

As shown in Figure 2, solid line indicates the groups treated with hard water and dashed line indicates the groups without hard water. The two lines are nonparallel to each other and exhibit a rising trend with the increase of dosage, indicating that glyphosate and hard water appeared to have a synergistic effect on the levels of $\beta_{2}-M G, A L B$, and $\mathrm{SCr}$ in mice. Glyphosate alone elevated the levels of $\beta_{2}-M G$, $\mathrm{ALB}$, and SCr, and this effect was amplified when the dose was increased. When glyphosate was combined with hard water, the levels of $\beta_{2}-M G, A L B$ and SCr were significantly increased after 30 and 90 days.

\section{Histopathological changes in the kidneys of mice}

Histopathological examinations were performed to investigate the combined effect of glyphosate and hard water on renal injury in mice. Under light microscopy, the kidneys from control mice showed complete renal glomerulus and tubule morphology. The epithelial cells of the tubule were arranged in order, with close intercellular adhesion. Slight edema and inflammatory cell infiltration were observed. After treatment with glyphosate, the epithelial cells of the renal tubule showed swelling, caryolysis, and exfoliation, accompanied by proliferation of interstitial fibroblasts and infiltration of inflammatory cells. The cytoplasmic vacuolization of tubular epithelial cells and fibroblast proliferation were more pronounced in mice administered $400 \mathrm{mg} / \mathrm{kg}$ glyphosate compared to mice given $100 \mathrm{mg} / \mathrm{kg}$ glyphosate. In mice treated with glyphosate combined with hard water, more severe tissue injury was observed, including vacuolar degeneration of renal tubular epithelial cells and increased fibroblast density in the mesenchyme. This was particularly pronounced in the $400 \mathrm{mg} / \mathrm{kg}$ glyphosate plus hard water group (Figure 3).

\section{Effects of glyphosate and hard water on kidney cell apoptosis and ultrastructure}

A few TUNEL-positive cells were observed in the kidneys of control mice and mice given hard water. However, the percentage of TUNEL-positive cells increased in glyphosate-treated mice. When glyphosate and hard water were administered together, more apoptotic cells were observed compared with mice treated with glyphosate alone. There was no significant difference between the control group and the group given hard water alone (Figure 4A). Electron microscopy observations revealed specific ultrastructural changes in the renal tubular epithelial cells following treatment with glyphosate. The renal tubules of mice in the control group and the hard water group showed a normal appearance. In glyphosate group, mitochondria were partially damaged, appeared mildly swollen and irregularly shaped. After 90 days of administering glyphosate and hard water together, the renal cortex of the mice were examined by electron microscopy and intracellular edema was observed. This was manifested as mitochondrial swelling and fracture, destruction 
A

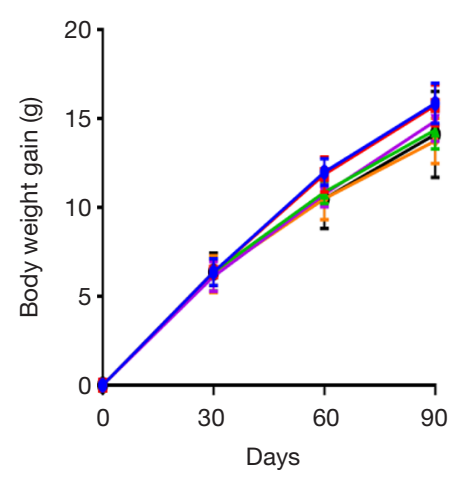

$\mathrm{E}$

90 day

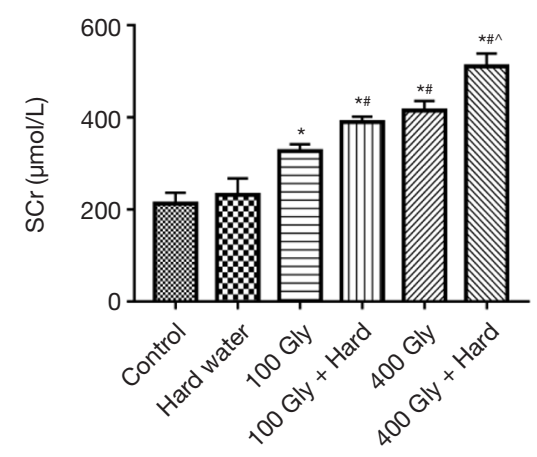

B

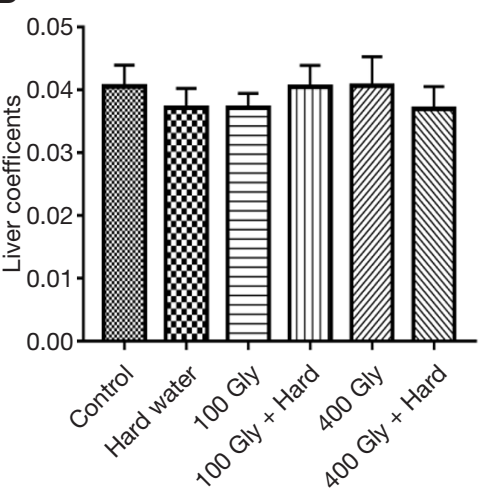

C

30 day
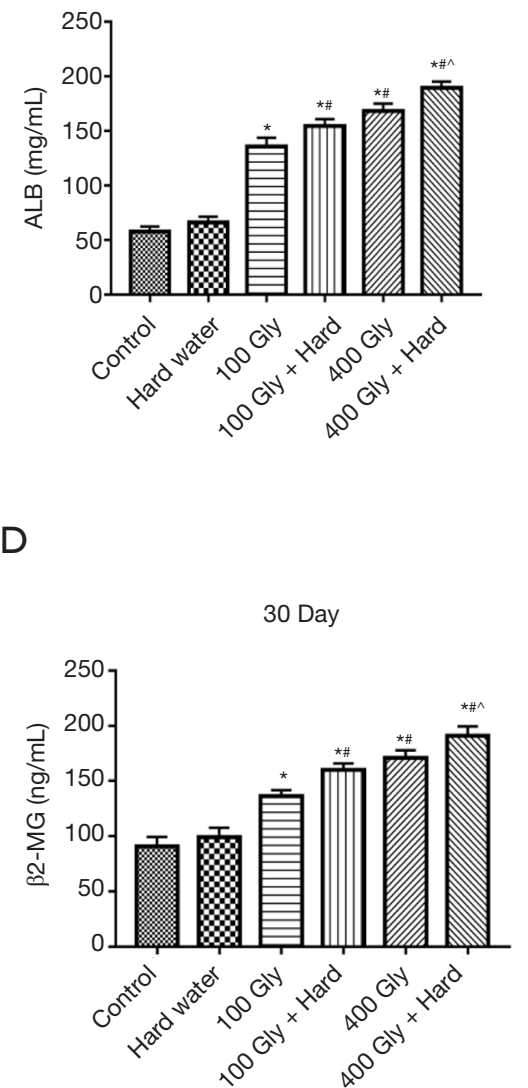

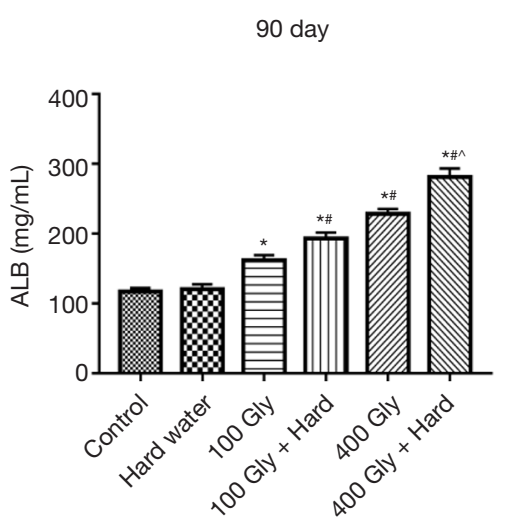

90 Day

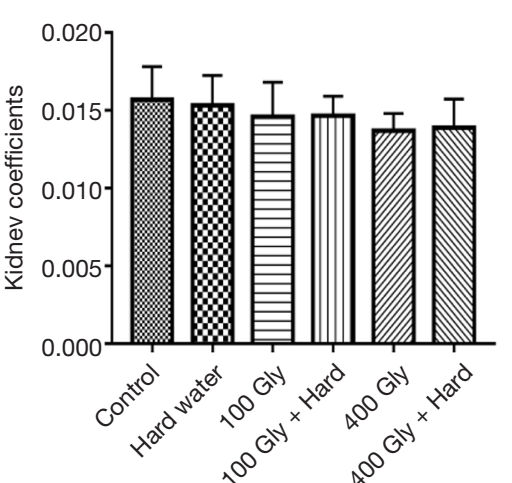

90 day

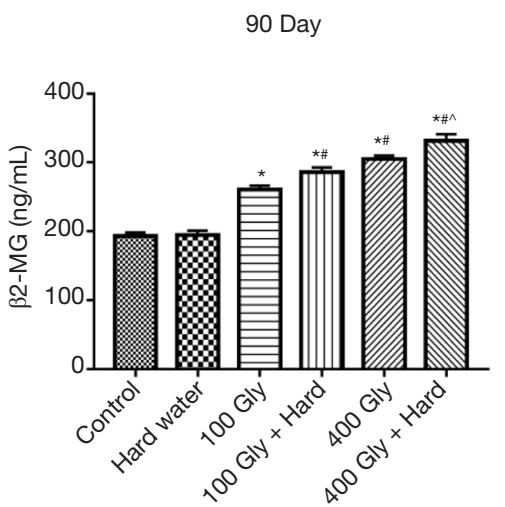

Figure 1 The effects of glyphosate and hard water on the kidneys of ICR mice. (A) Body weight gain; (B) liver and kidney coefficient; (C) ALB levels; (D) $\beta_{2}$-MG levels; (E) SCr levels. *, $\mathrm{P}<0.05$ compared with controls; *, $\mathrm{P}<0.05$ compared with $100 \mathrm{mg} / \mathrm{kg}$ glyphosate; ^, $\mathrm{P}<0.05$ compared with $400 \mathrm{mg} / \mathrm{kg}$ glyphosate. ICR, Institute of Cancer Research; Gly, glyphosate; ALB, albumin; $\beta_{2}-\mathrm{MG}, \beta_{2}$-microglobulin; $\mathrm{SCr}$, serum creatinine. 
A

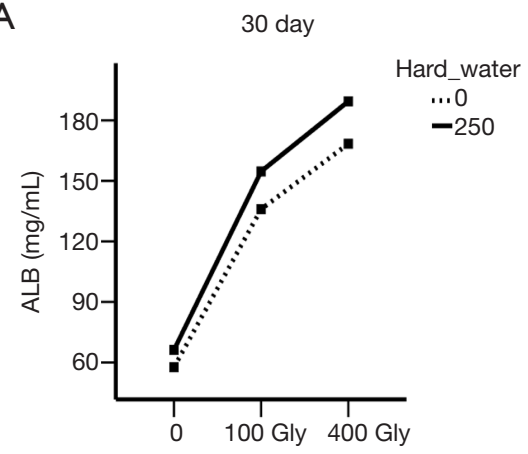

B

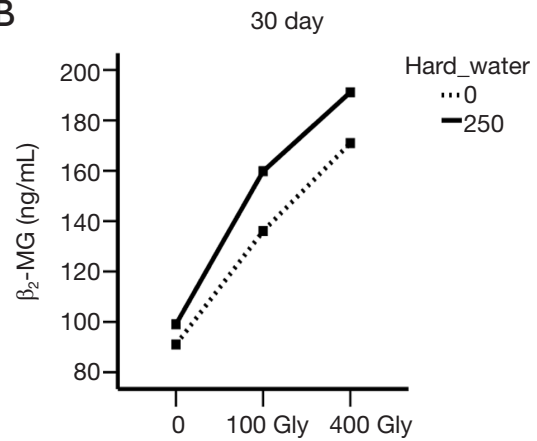

C

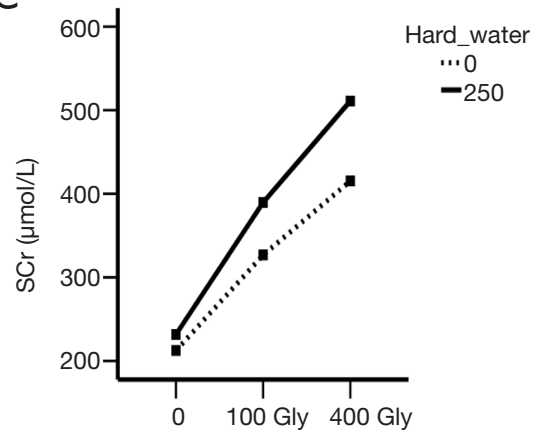

90 day

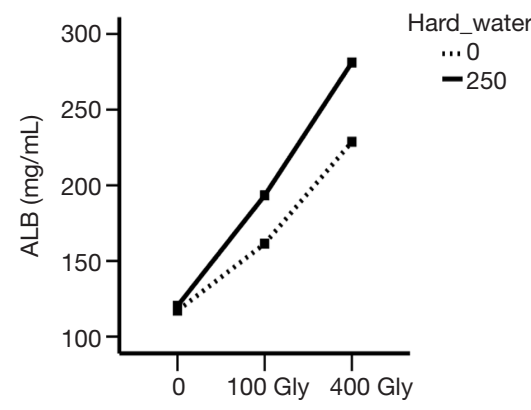

90 day

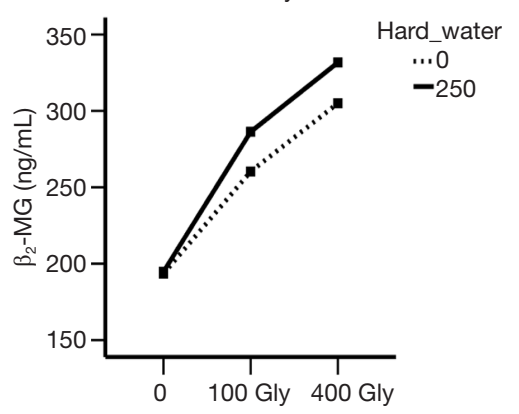

Figure 2 Interaction plots between the two factors, glyphosate and hard water. (A) The effect of glyphosate and hard water on ALB levels; (B) the effect of glyphosate and hard water on $\beta_{2}$-MG levels; (C) the effect of glyphosate and hard water on SCr. Gly, glyphosate; ALB, albumin; $\beta_{2}-\mathrm{MG}, \beta_{2}$-microglobulin; SCr, serum creatinine.

of the mitochondrial double membrane structure and mitochondrial cristae disappeared. Rough endoplasmic reticulum expansion and degranulation were also observed (Figure 4B).

\section{Effects of glyphosate and hard water on renal CaSR and cPLA $A_{2}$}

As has been reported previously (11), NMDAR1-positive expression were detected in kidneys from glyphosate-treated mice compared to control mice (Figure $5 A$ ). Increasing evidence has shown that the CaSR is substantially expressed within the renal tissue $(22,23)$. This study confirmed that the CaSR is intensely expressed on proximal tubules and thick ascending limb of the mouse kidney (Figure 5B). The effect of $\mathrm{Ca}^{2+}$ cations in hard water on the renal CaSR was examined. The kidneys of mice treated with hard water demonstrated higher expression of the CaSR compared to control mice. The levels of CaSR expression in the kidneys of glyphosate-treated mice was not statistically different to that observed in control mice (Figure 5C). $\mathrm{PLA}_{2}$ is activated by phosphorylation at serine- 505 by MAPKs (24). This results 
A

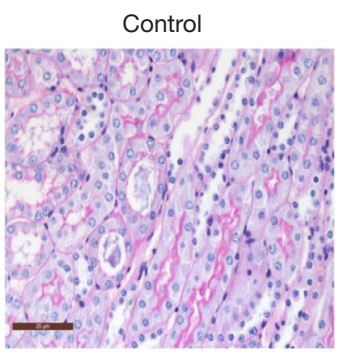

100 Gly + Hard

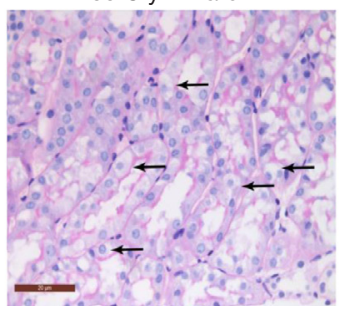

B

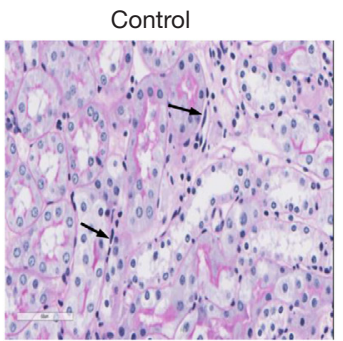

100 Gly + Hard

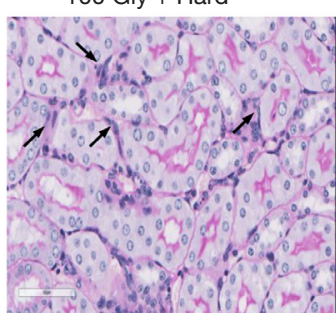

Hard water

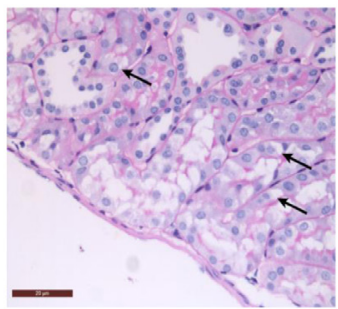

400 Gly

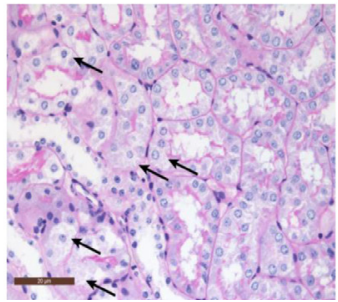

Hard water

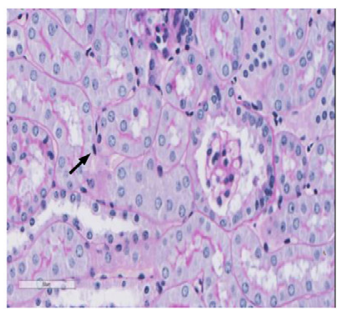

400 Gly

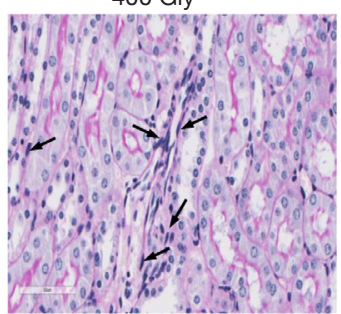

100 Gly

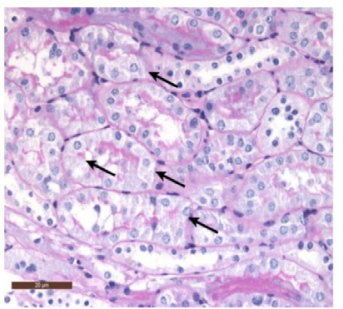

400 Gly + Hard

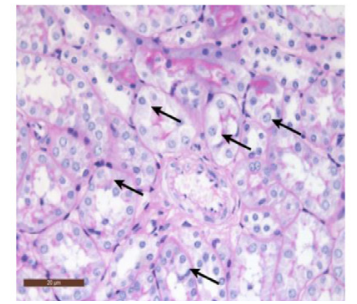

100 Gly

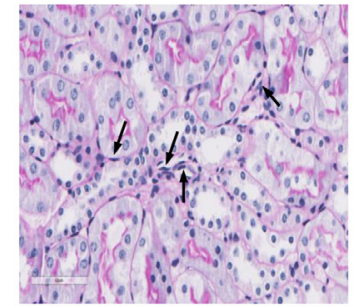

400 Gly + Hard

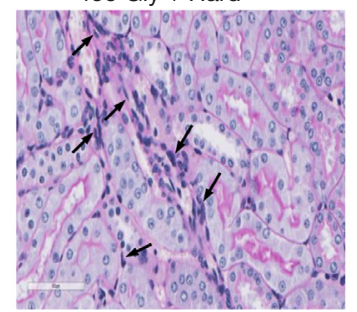

C

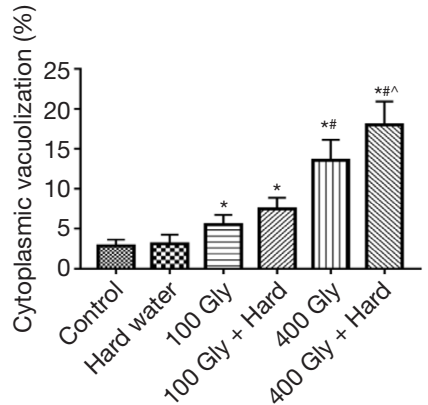

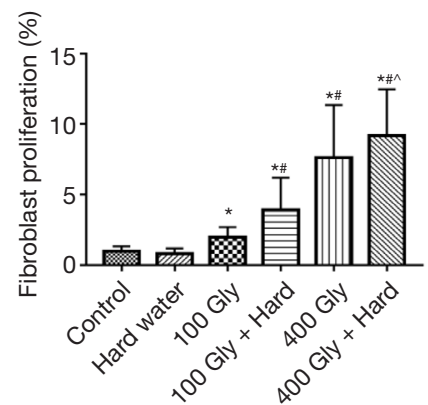

Figure 3 PAS-stained sections. (A) Vacuolar degeneration in epithelium cells, bar $=20 \mu \mathrm{m}$, black arrows show cytoplasmic vacuolization; (B) proliferation of interstitial fibroblasts, bar $=60 \mu \mathrm{m}$, black arrows show fibroblast hyperplasia; (C) quantification of pathology. *, $\mathrm{P}<0.05$ compared with controls; ", $\mathrm{P}<0.05$ compared with $100 \mathrm{mg} / \mathrm{kg}$ glyphosate; ^, $\mathrm{P}<0.05$ compared with $400 \mathrm{mg} / \mathrm{kg}$ glyphosate. Gly, glyphosate; PAS, periodic acid-schiff. 
A

Control

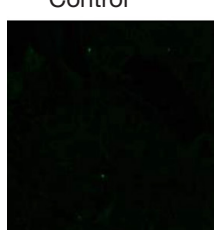

DAPI

Merge
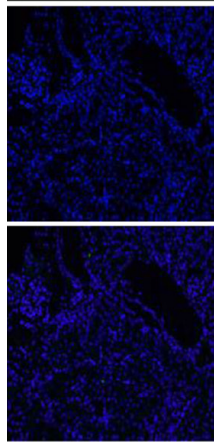

Hard water
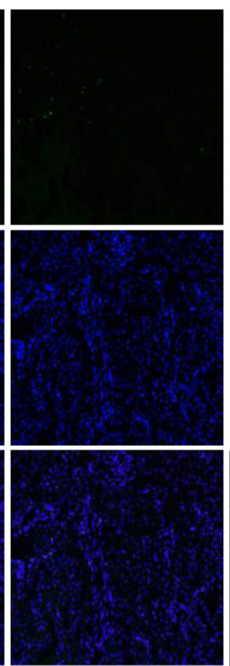

B
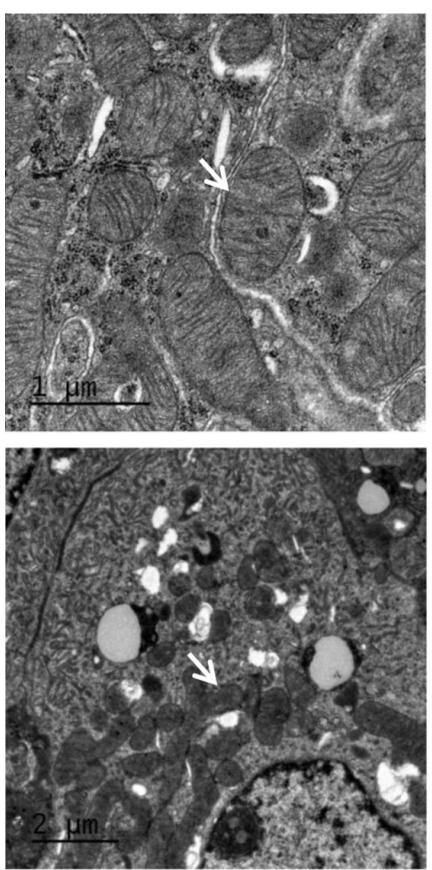

100 Gly
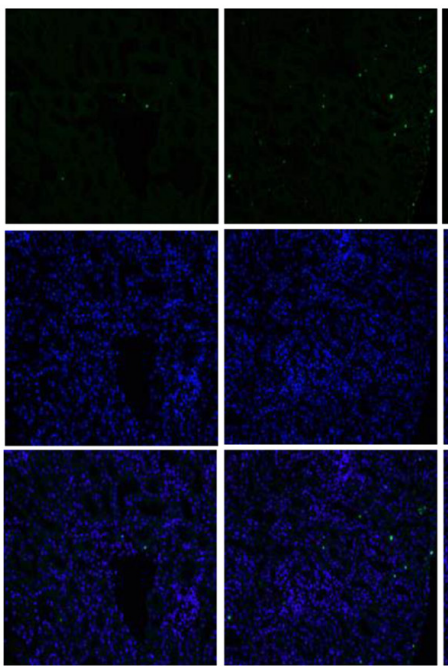

Gly
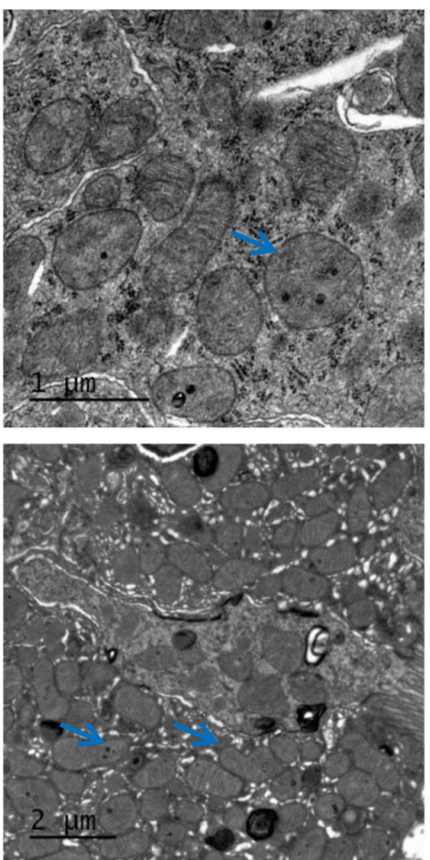

400 Gly

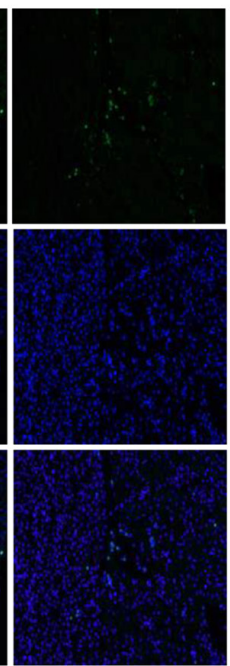

400 Gly + Hard

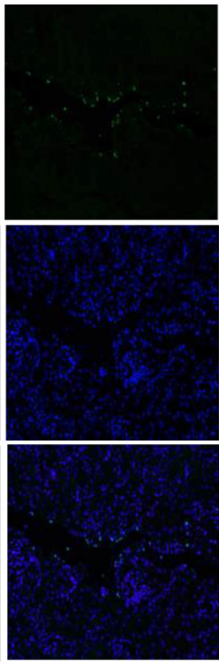

Gly + Hard water
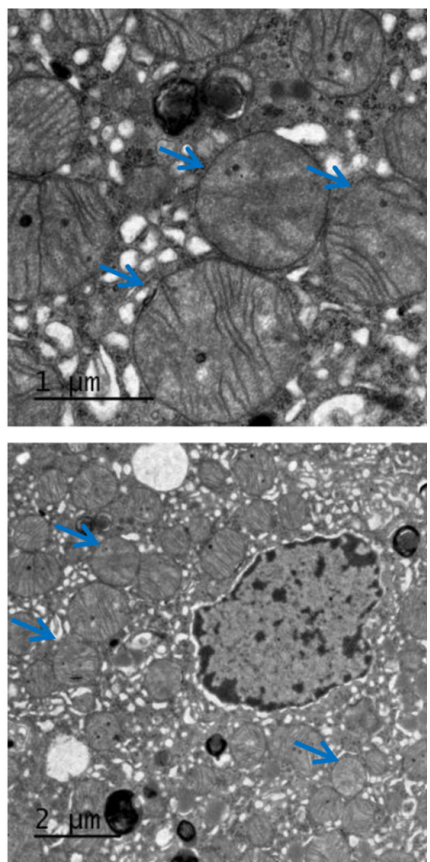

Figure 4 The detection of renal tubular epithelial cell death. (A) TUNEL staining. Green cells indicate TUNEL-positive cells, 200x magnification; (B) ultrastructural analysis of kidney tissue. In the control group, mitochondrial morphology was normal with preserved membranes and cristae (arrow). Mitochondrial swelling and cristae rupture (blue arrow) were observed in glyphosate and glyphosate plus hard water groups. TUNEL, terminal deoxynucleotidyl transferase-mediated dUTP-biotin nick end labeling; Gly, glyphosate.

in the release of AA and its metabolites cascade, which are associated with inflammatory reactions and oxidative stress $(25,26)$. Western blot analyses were performed to determine the levels of $\mathrm{t}-\mathrm{cPLA} \mathrm{A}_{2}$ and $\mathrm{p}-\mathrm{cPLA} \mathrm{A}_{2}$ protein expression in the kidneys of the mice. The levels of $\mathrm{p}-\mathrm{cPLA}_{2}$ protein in the kidneys of glyphosate-treated mice was significantly higher than the levels observed in control mice (Figure 5D). However, the increase in $\mathrm{p}-\mathrm{CPLA}_{2}$ protein levels was more pronounce in mice treated with glyphosate and hard water together. The treatment of mice with hard water alone did 
A
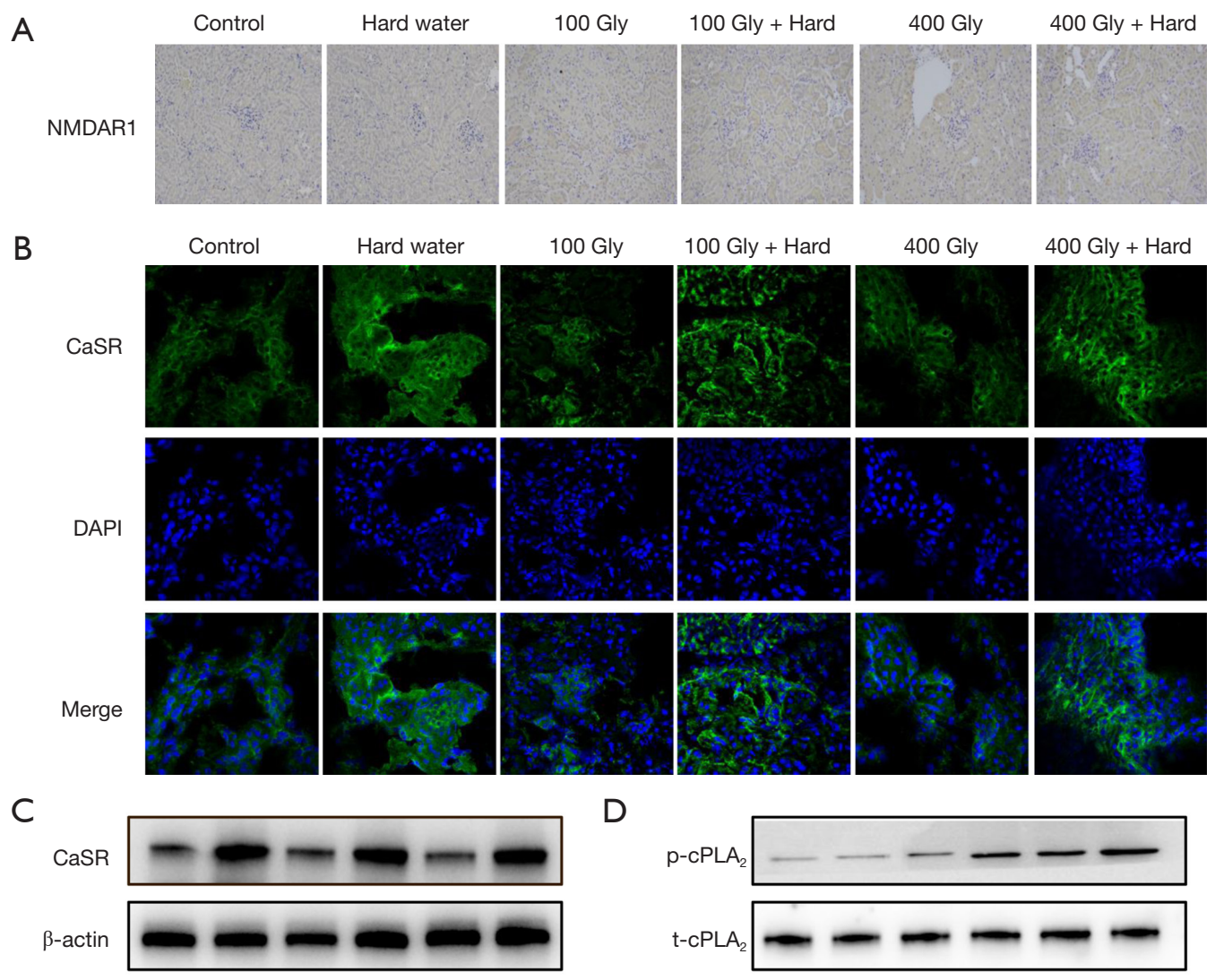

D
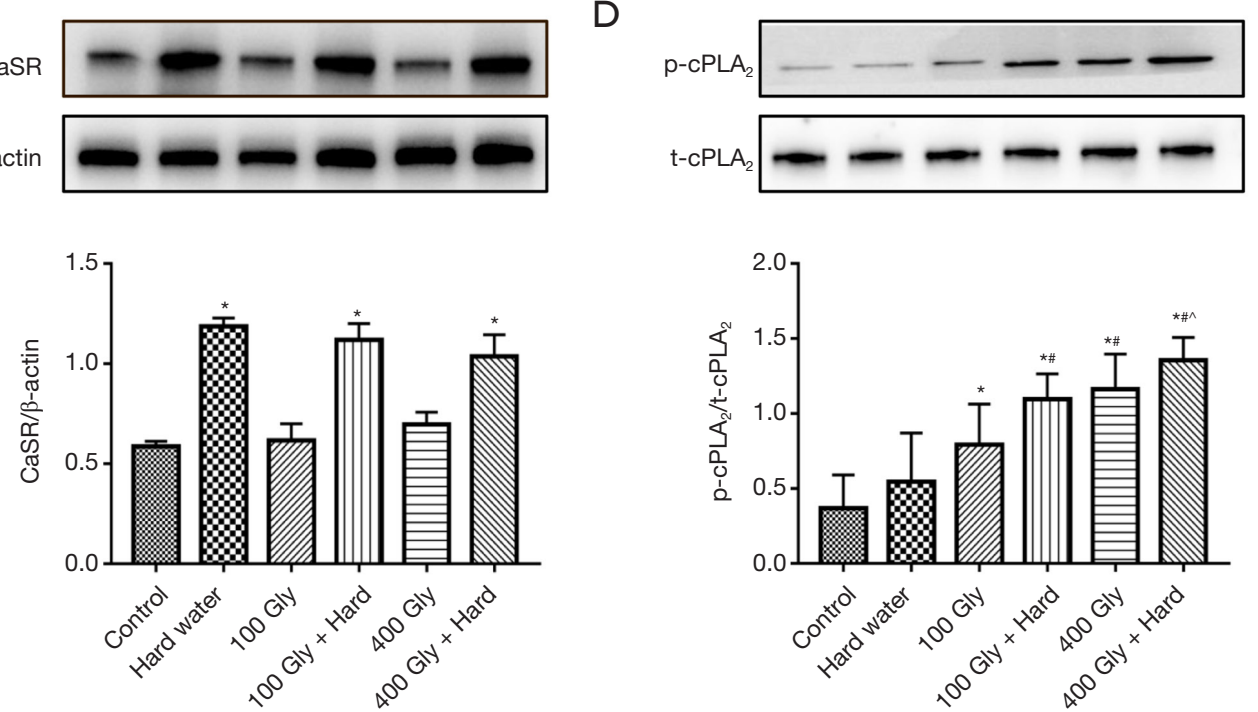

Figure 5 The levels of CaSR and cPLA expression in the renal tissue. (A) immunohistochemical staining of NMDAR1 in kidneys (yellow staining indicates NMDAR1-positive expression), 200x magnification; (B) immunocytochemical localization of CaSR in mouse renal tissue,

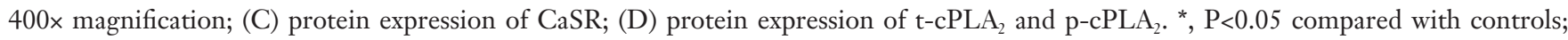
", $\mathrm{P}<0.05$ compared with $100 \mathrm{mg} / \mathrm{kg}$ glyphosate; ^, $\mathrm{P}<0.05$ compared with $400 \mathrm{mg} / \mathrm{kg}$ glyphosate. Gly, glyphosate; CaSR, calcium-sensing receptor; p-cPLA 2 , phosphorylated-cPLA $;$ t-cPLA 2 , total $\mathrm{cPLA}_{2}$.

not lead to any alterations in $\mathrm{p}-\mathrm{CPLA}_{2}$ protein expression compared with the control group. The results showed that the protein levels of $\mathrm{t}-\mathrm{cPLA} \mathrm{A}_{2}$ were similar in all 6 treatment groups, suggesting a regulatory effect of glyphosate and hard water together on $\mathrm{CPLA}_{2}$ phosphorylation.
We further analyzed the expression of CaSR and p-cPLA using flow cytometry studies. The proportion of cells in the kidney expressing the CaSR was significantly increased in mice that were given hard water compared to control mice. However, there were no significant differences 
between mice treated with glyphosate and control mice (Figure 6A). In the kidney of mice treated with glyphosate, the proportion of cells expressing the $\mathrm{p}-\mathrm{CPLA} \mathrm{C}_{2}$ protein was significantly increased compared to the control mice (Figure 6B). This increase was significantly amplified in mice treated with both glyphosate and hard water.

\section{Effects of glyphosate and hard water on renal inflammation and oxidative stress in mice}

The levels of TX-A $2, \mathrm{LTB}_{4}, \mathrm{PGE}_{2}$, NOS, and NO were significantly increased in the groups exposed to glyphosate compared with the control group, with $400 \mathrm{mg} / \mathrm{kg}$ glyphosate resulting in a more pronounced increase compared to $100 \mathrm{mg} / \mathrm{kg}$ glyphosate. The combination of glyphosate with hard water resulted in higher levels of TX- $\mathrm{A}_{2}, \mathrm{LTB}_{4}$, $\mathrm{PGE}_{2}$, NOS, and $\mathrm{NO}$ compared to mice given glyphosate alone, with the $400 \mathrm{mg} / \mathrm{kg}$ glyphosate plus hard water group showing the most significant increase. Parameters of oxidative stress, such as SOD and GSH-Px, were measured. The levels of SOD and GSH-Px were relatively high in the control group and the hard water group. In contrast, the levels of SOD and GSH-Px in the $100 \mathrm{mg} / \mathrm{kg}$ glyphosate group decreased and further significant decreases were observed in mice treated with $400 \mathrm{mg} / \mathrm{kg}$ glyphosate. When glyphosate and hard water were given together, the SOD and GSH-Px levels were remarkably decreased compared with mice given glyphosate alone (Figure 7).

\section{The synergistic effect of glyphosate and hard water on inflammation and oxidative stress}

The results of the analysis of variance demonstrated an interaction between glyphosate and hard water (Figure 8). The interaction plots showed that treatment with glyphosate alone significantly increased the levels of TX-A $\mathrm{A}_{2}, \mathrm{LTB}_{4}, \mathrm{PGE}_{2}$, NOS, NO and the effect was more pronounce with the increased dosage. When hard water was given alone, there was no significant difference in each index. Furthermore, glyphosate and hard water showed a synergistic effect on the activation of inflammation markers. No interaction between SOD and GSH-Px was observed.

\section{Discussion}

The interaction between glyphosate and hard water has been a major focus of recent research, especially in relation to its impact on CKDu $(27,28)$. Although glyphosate alone and hard water alone may not cause an epidemic of chronic kidney disease, when combined together, they could form complexes with nephrotoxic metals and cause renal damage (29). A multivariable analysis performed by Lunyera et al. (27) demonstrated that exposure to hard water and glyphosate together was associated with higher odds of developing CKDu. The adjusted odds ratios for drinking hard water together with exposure to intermediate or high concentrations (median $3.2 \mu \mathrm{g} / \mathrm{L}$ ) of glyphosate were 2.5 (95\% confidence interval: $1.1-5.7)$ and 5.5 (95\% confidence interval: 2.9-10.3), respectively. Soft water with traces or no detectable level of glyphosate was used as a reference. A significant positive association between hard water consumption and the occurrence of $\mathrm{CKDu}$ has been previously reported (30). One study demonstrated that $96 \%$ of patients who developed CKDu had been exposed to hard or very hard water over a 5-year period (31). While there has been much evidence in the literature demonstrating that CKDu is affected by hard water and a number of other factors, the details and mechanisms of this relationship are not well understood $(32,33)$. There has been much research examining the relationship between glyphosate and CKDu. While glyphosate is widely used and generally considered to be safe for humans and animals, several animal studies have shown evidence of neurotoxicity, endocrine disruption, cell damage, and immune suppression due to glyphosate (34). In addition, glyphosate-induced toxicity to the renal tubules has been reported, suggesting that the kidney is an important target organ of glyphosate (35). In fact, Wunnapuk and colleagues (36) have demonstrated a link between glyphosate and renal injury in rats. Furthermore, our previous studies confirmed that acute glyphosate exposure can cause epithelial cell damage in renal tubules mediated by changes to the NMDAR, calcium influx, and oxidative stress (11).

This study explored the role of hard water and glyphosate in renal tubular injury. The results demonstrated that hard water alone did not cause any direct health risks to the mice. Therefore, we hypothesized that hard water acts synergistically to enhance renal tubular injury induced by glyphosate. Well-water used in CKDuendemic areas contain higher levels of $\mathrm{Ca}^{2+}$ compared to $\mathrm{Mg}^{2+}$ (29 vs. $\left.13 \mathrm{mg} / \mathrm{L}\right)$ (37). Similar findings have been reported in China, with calcium salt content accounting for about $70 \%$ of the total hardness in the water. The CaSR is a homodimeric G-protein-coupled receptor, highly expressed in parathyroid glands and kidneys, and plays a substantial role in systemic calcium metabolism. In the 
A
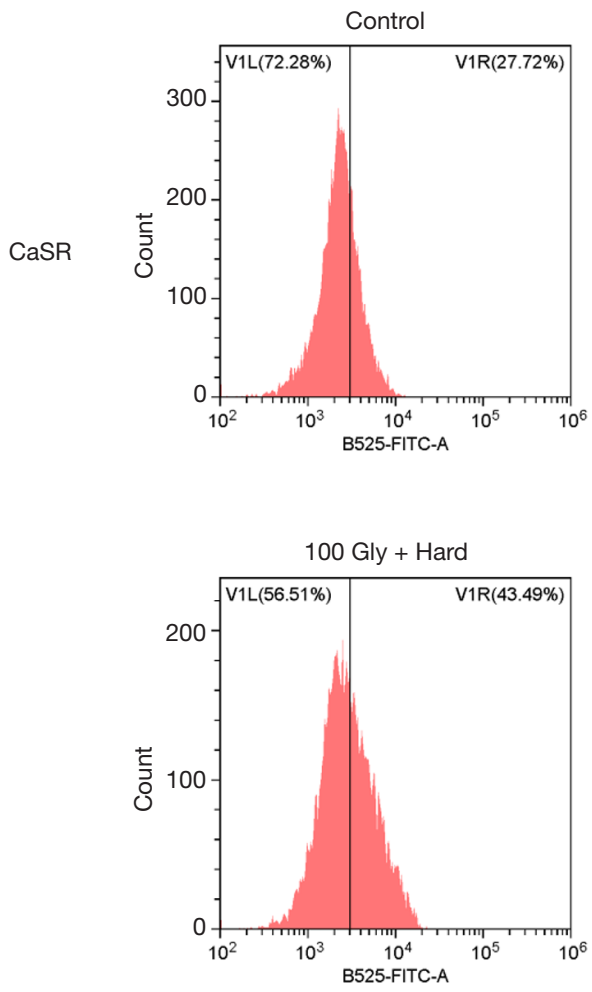

B
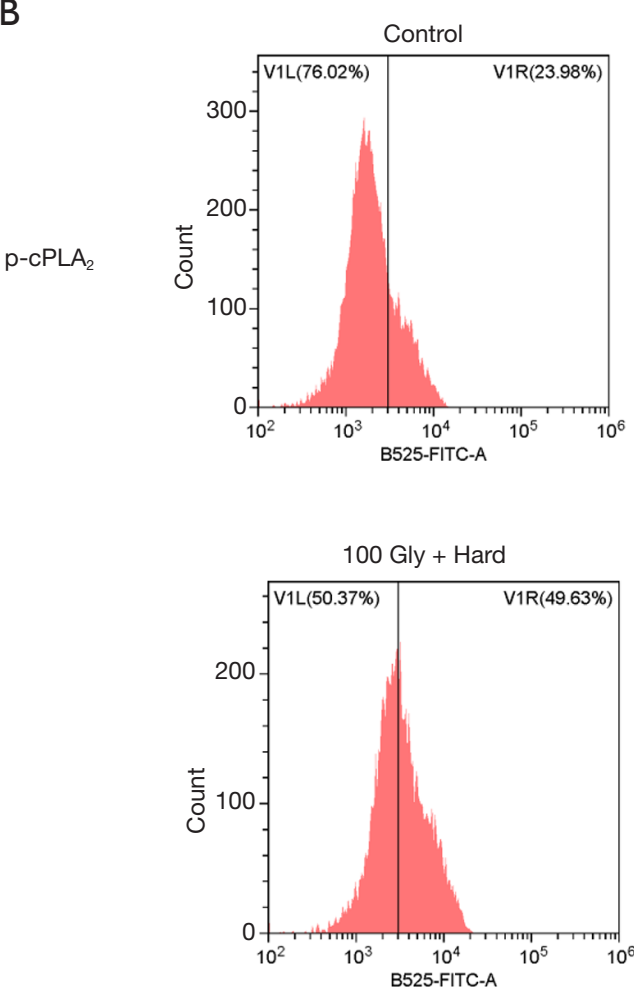
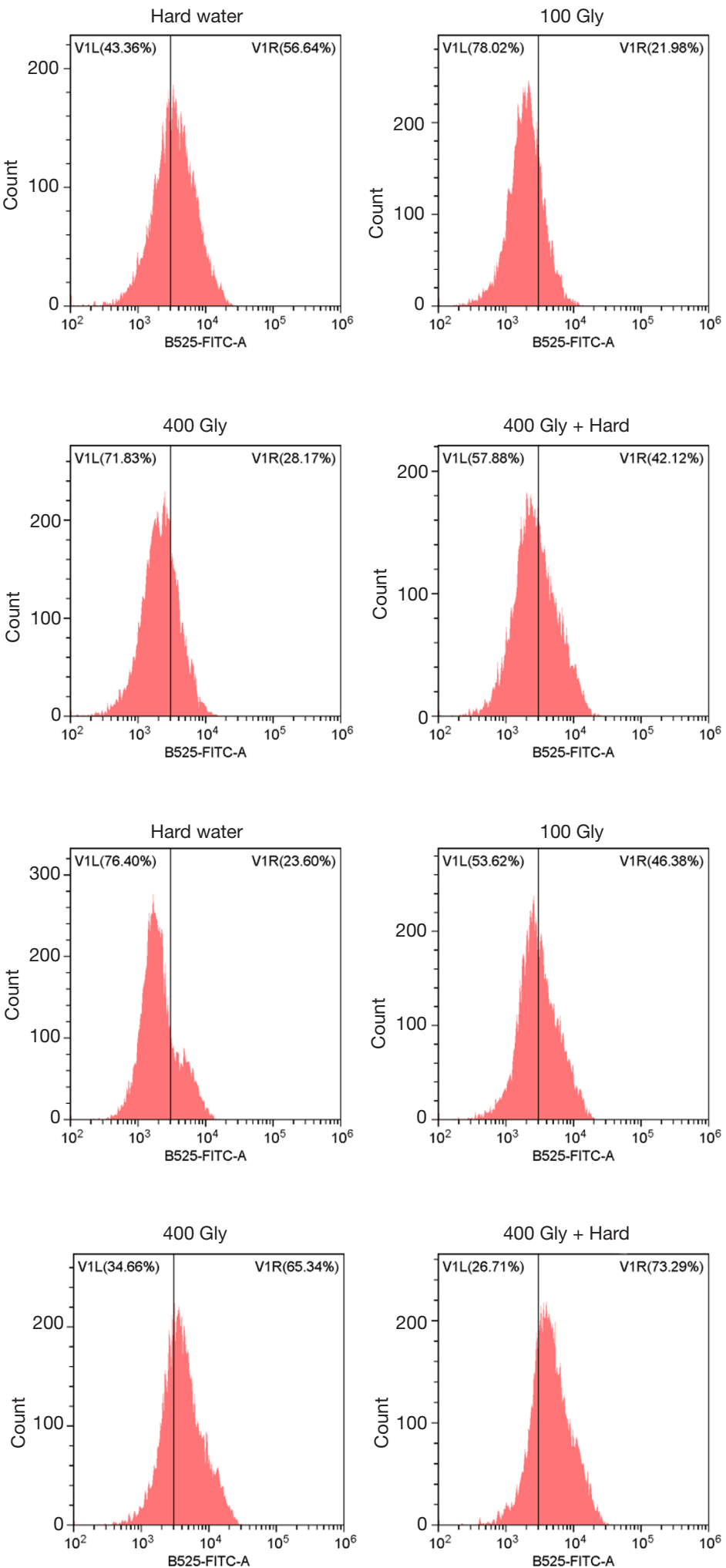

Figure 6 The ratio of protein expression of CaSR and p-cPLA 2 . (A) Flow cytometric analysis of CaSR; (B) flow cytometric analysis of p-cPLA 2 . Gly, glyphosate; CaSR, calcium-sensing receptor; p-cPLA 2 , phosphorylated-cPLA . $_{2}$ 

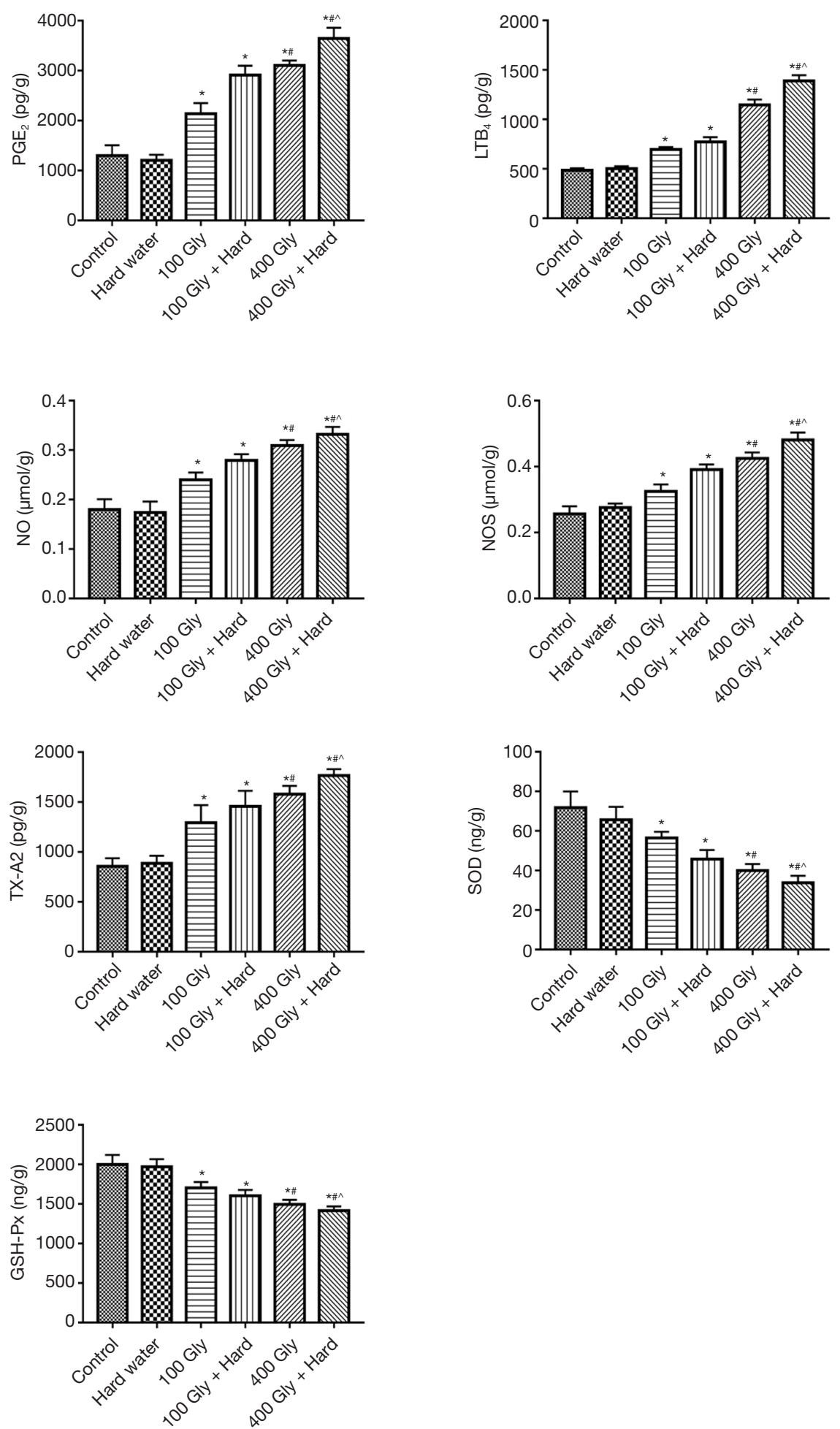

Figure 7 The effects of glyphosate and hard water on oxidative stress and inflammatory indexes in renal tissue. *, $\mathrm{P}<0.05$ compared with controls; ", $\mathrm{P}<0.05$ compared with $100 \mathrm{mg} / \mathrm{kg}$ glyphosate; ^, $\mathrm{P}<0.05$ compared with $400 \mathrm{mg} / \mathrm{kg}$ glyphosate. Gly, glyphosate; TX$\mathrm{A}_{2}$, thromboxane $\mathrm{A}_{2} ; \mathrm{LTB}_{4}$, leukotriene $\mathrm{B}_{4}$; $\mathrm{PGE}_{2}$, prostaglandin $\mathrm{E}_{2}$; NOS, nitric oxide synthase; NO, nitric oxide; GSH-Px, glutathione peroxidase. 

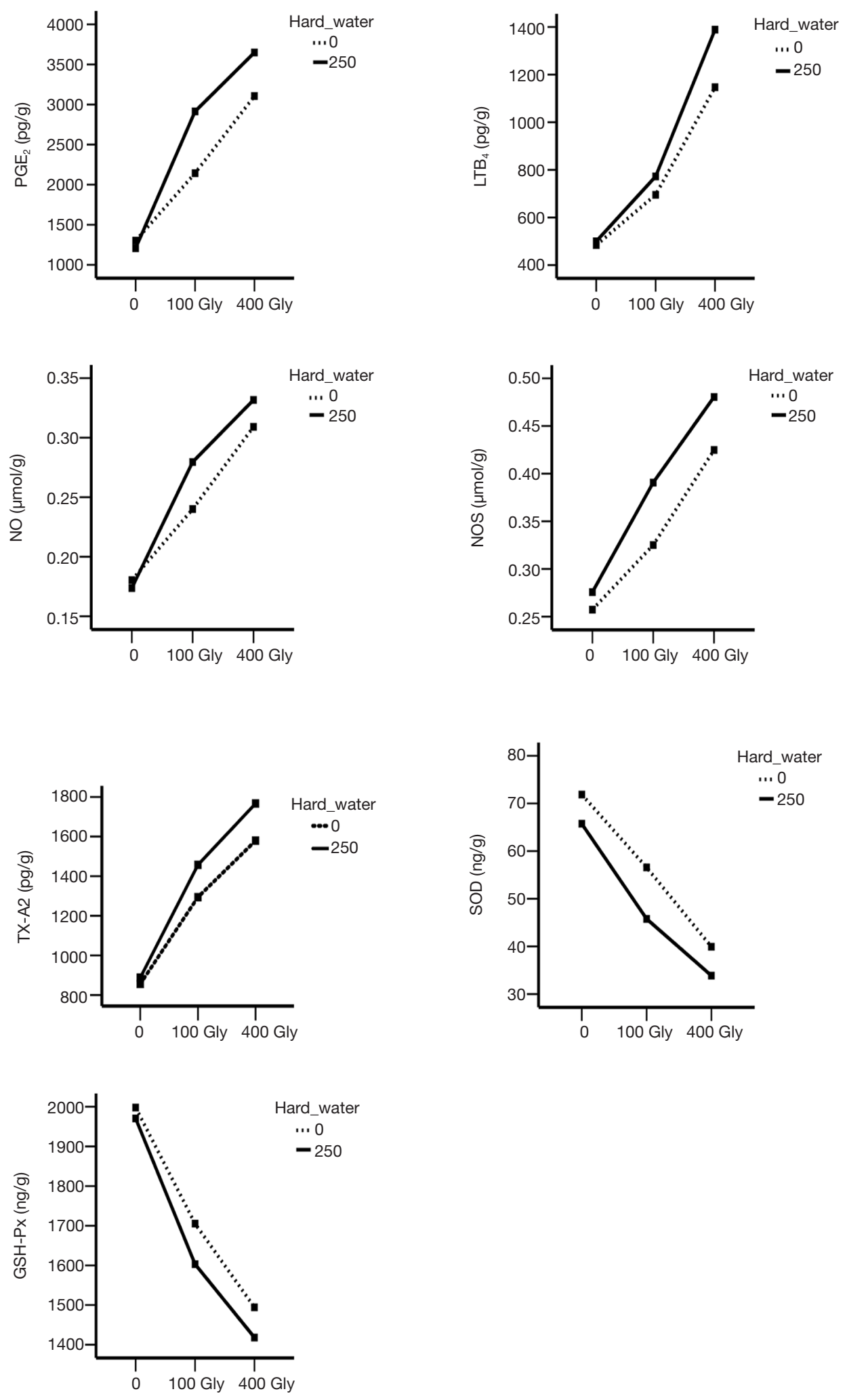

Figure 8 The synergistic effect of glyphosate and hard water on inflammatory biomarkers. Gly, glyphosate; TX- $\mathrm{A}_{2}$, thromboxane $\mathrm{A}_{2}$; $\mathrm{LTB}_{4}$, leukotriene $\mathrm{B}_{4}$; $\mathrm{PGE}_{2}$, prostaglandin $\mathrm{E}_{2}$; NOS, nitric oxide synthase; $\mathrm{NO}$, nitric oxide; GSH-Px, glutathione peroxidase. 
kidney, CaSR modulates electrolyte and water excretion, thereby regulating the function of different tubular segments. In particular, the CaSR reduces passive and active calcium reabsorption in distal tubules to maintain physiological ionized calcium concentrations in the serum. Further, it is reported that CaSR agonists such as $\mathrm{Ca}^{2+}$ and $\mathrm{Mg}^{2+}$ act through the heterotrimeric G-proteins $\mathrm{Gq}, \mathrm{Gi}$ and G12/13. Activation of G(q) stimulates phospholipase $\mathrm{C}$, and inositol 1,4,5-trisphosphate, releasing calcium from intracellular stores (38-40). In physiological situations, the activity of CaSR is partially activated by the presence of an agonist. The degree correlated with the concentration and time of agonist. The elevated calcium levels stimulate the renal CaSR, thus promoting migration of newly synthesized receptors to the cell membrane (41). In this study, the expression of CaSR protein in the kidney tissue increased following exposure to hard water alone or hard water combined with glyphosate. However, expression of the CaSR in mice treated with glyphosate alone was not statistically different compared to the control mice. This suggested that continuous exposure to hard water may activate the renal CaSR, which may be one of the key mechanisms of kidney damage induced by combined exposure to hard water and glyphosate.

The CaSR has been shown to interact with MAPK, ${ } \mathrm{PLA}_{2}$ and the epidermal growth factor. Of the phospholipase A2 (PLA2) enzymes, cytosolic phospholipase A2 (cPLA2) has a unique set of biochemical properties, which is regulated by calcium and MAPKs, releasing arachidonic acid. The metabolism of arachidonic acid by cyclooxygenase (COX) enzymes or 5-lipoxygenase (5-LO) generates eicosanoids, lipid mediators capable of triggering cellular responses, which contributes to inflammation $(42,43)$. Glyphosate-induced cytotoxicity has been observed in HK-2 cells and it has been shown that the renal effect of glyphosate relies on activation of the NMDAR, which results in intracellular calcium overload and increased oxidative stress. Exposure of neurons from different brain regions to NMDA has been reported to activate cPLA through the $\mathrm{Ca}^{2+}$ mechanism (44). Our results showed that levels of $\mathrm{p}-\mathrm{cPLA}_{2}$ were increased in mice treated with glyphosate compared with control mice, and protein levels of p-cPLA $\mathrm{C}_{2}$ was higher at the $400 \mathrm{mg} / \mathrm{kg}$ dose compared to the $100 \mathrm{mg} / \mathrm{kg}$ dose. Moreover, the increase was more apparent when hard water was offered in combination with glyphosate. These data suggested that $\mathrm{CPLA}_{2}$ is involved in the interaction between glyphosate and the $\mathrm{Ca}^{2+}$ cations in the hard water, presumably through activation of the
NMDAR and the CaSR.

To explore the effects of $\mathrm{CPLA}_{2}$ and its downstream pathways on renal function, biomarkers related to renal inflammation, including TX-A $\mathrm{A}_{2} \mathrm{LT}_{4}, \mathrm{PGE}_{2}$, NOS, and NO, were assessed. Exposure to glyphosate (100 and $400 \mathrm{mg} / \mathrm{kg}$ ) significantly increased the levels of TX$\mathrm{A}_{2}, \mathrm{LTB}_{4}, \mathrm{PGE}_{2}$, NOS, and NO, and the increase was even higher when used in combination with hard water. Active $\mathrm{CPLA}_{2}$ is responsible for the delivery of AA, with the ensuing release of $\mathrm{TXA}_{2}, \mathrm{LTB}_{4}$ and $\mathrm{PGE}_{2}$, which are associated with diverse physiological effects, as well as inflammatory responses and tumor dissemination $(45,46)$. Prostaglandins (PGs) are biosynthesized by the COX enzymes, either constitutively or in response to cell specific trauma, stimuli, or signaling molecules $(47,48)$. $\mathrm{PGE}_{2}$ is the most abundantly detected PG in various tissues (49). It has been shown to induces chronic inflammation and various autoimmune diseases through $\mathrm{T}$ helper 1 (Th1)cell differentiation, Th17-cell proliferation, and IL22 production from Th22 cells via the prostaglandin E receptor 2 and prostaglandin $\mathrm{E}$ receptor $4(50,51)$. Additionally, $\mathrm{PGE}_{2}$ was found to exacerbate acute inflammation by inducing vascular hyperpermeability and recruiting neutrophils via the prostaglandin $\mathrm{E}$ receptor 3 in mast cells, resulting in swelling (52). TXA synthesized from AA via the actions of COX enzymes, can promote the synthesis of tumor necrosis factor- $\alpha(\mathrm{TNF}-\alpha)$ and interleukin-1B (IL-1B) $(53,54)$. Consistent with the above findings in animal models, Nakanishi and colleagues reported that the microsomal prostaglandin E synthase-1 knockout mice were generally protected against a variety of inflammatory disease phenotypes, including collageninduced arthritis, lipopolysaccharide (LPS)-induced bone loss, and antigen-induced paw edema (55). In addition to the above pro-inflammatory metabolites, $\mathrm{LTB}_{4}$ is another class of molecules that is rapidly generated from AA through the sequential action of 5-LO in response to various stimuli (56). $\mathrm{LTB}_{4}$ is well known to induce polymorphonuclear neutrophils and phagocytosis of macrophages (57). Extensive attention has been given to the role of $\mathrm{LTB}_{4}$ in acute and chronic inflammatory diseases, such as infectious diseases, allergies, autoimmune diseases, and metabolic diseases (58). More importantly, increases in NO production by inducible NOS was accompanied by $\mathrm{cPLA}_{2}$ activation (59). Through the reaction of $\mathrm{NO}$ with a superoxide anion, peroxynitrite is produced, which is cytotoxic and causes severe damage to other molecules in the cell $(60,61)$. Meanwhile, previous studies have highlighted the effect of $\mathrm{CPLA}_{2}$ on oxidative 
stress. Our results demonstrated lower levels of SOD and GSH-Px in mice exposed to glyphosate plus hard water, indicating that the endogenous antioxidant protective pathways of the mouse kidney were inadequate or overwhelmed. Free radical scavengers including catalase, SOD, and GSH-Px protect cells from ROS $(62,63)$. Several studies shown that $\mathrm{CPLA}_{2}$ can generate large amounts of superoxide through the "cPLA2-AA-NADPH oxidase" pathway, thereby disturbing the oxidant-antioxidant balance, and evoking inflammatory responses $(64,65)$. This is consistent with our observations.

The effects of glyphosate and hard water on the changes in the biomarkers of renal function were examined. Urine $\beta_{2}-$ MG, ALB and serum creatinine levels in mice administered glyphosate were higher than those in the control group, but lower than the levels observed in mice treated with the combination of glyphosate plus hard water. The increase in the levels of $\beta_{2}-M G$ in the urine indicated an impairment of tubular reabsorption, while the increase in the levels of ALB reflected the impairment of glomerular function. Our results demonstrated that prolonged exposure to glyphosate led to renal impairment, and the combined effect of hard water was more pronounce. Combination treatment of glyphosate and hard water enhanced cellular edema, and interstitial fibroblast proliferation. Similarly, the TUNEL assay confirmed the increase in renal tubular cell apoptosis in mice exposed to glyphosate and hard water. $\mathrm{CPLA}_{2}$ has been demonstrated to be involved in various cytotoxic reactions, and its downstream product AA may stimulate apoptosis through activation of sphingomyelinase (66). Several recent reports also suggested that the release of AA parallels the reduction in cell viability and DNA fragmentation $(67,68)$. Moreover, continuous chronic inflammations promote the transformation of renal interstitial cells to fibroblasts $(69,70)$. As noted by Montford and colleagues (71), cPLA $\mathrm{PL}_{2}$ wighly expressed in patients with chronic nephritis and in animal models of glomerulonephritis. In this current study, there was no significant difference in renal function index and pathological results between the control mice and mice given hard water, which indicated that hard water, at the concentration used in this study, did not cause renal tubular damage.

This study demonstrated the possible combined effect of glyphosate and hard water on renal damage. Both glyphosate and hard water are risk factors for renal disease. This study is limited by the short study timeframe and future studies examining the effects of a lifetime exposure to glyphosate would be insightful. We merely performed the in vivo experiment, and the in vitro experiment will be performed in our following experiments. Overexpression and downregulation experiments of phospholipase $\mathrm{A}_{2}$ are required to verify the observations in this study

\section{Conclusions}

In conclusion, we demonstrated that the CaSR may be activated after continuous exposure to hard water, leading to renal tubular epithelial cells injury. Glyphosate exerts a synergistic effect though the MAPK/cPLA $/$ AA signaling pathway. The findings of this study provide a theoretical basis and reference point for evaluating the risk of glyphosate and hard water. Furthermore, $\mathrm{cPLA}_{2}$ may be a therapeutic target for renal damage induced by glyphosate and hard water.

\section{Acknowledgments}

The authors wish to thank all the study participants, research staff and students who participated in this work. Funding: The research is supported by National Natural Science Foundation of China (41821005), and international partnership program of Chinese academy of sciences (121311KYSB20190071).

\section{Footnote}

Reporting Checklist: The authors have completed the ARRIVE reporting checklist. Available at http://dx.doi. org/10.21037/atm-20-7739

Data Sharing Statement: Available at http://dx.doi. org/10.21037/atm-20-7739

Conflicts of Interest: All authors have completed the ICMJE uniform disclosure form (available at http://dx.doi. org/10.21037/atm-20-7739). The authors have no conflicts of interest to declare.

Ethical Statement: The authors are accountable for all aspects of the work in ensuring that questions related to the accuracy or integrity of any part of the work are appropriately investigated and resolved. Animal experiments were approved by the Fudan University Animal Care and Use Committee, in accordance with the Guide for the Care and Use of Laboratory Animals issued by the Ministry of 
Health of the People's Republic of China.

Open Access Statement: This is an Open Access article distributed in accordance with the Creative Commons Attribution-NonCommercial-NoDerivs 4.0 International License (CC BY-NC-ND 4.0), which permits the noncommercial replication and distribution of the article with the strict proviso that no changes or edits are made and the original work is properly cited (including links to both the formal publication through the relevant DOI and the license). See: https://creativecommons.org/licenses/by-nc-nd/4.0/.

\section{References}

1. Jayasinghe $\mathrm{S}, \mathrm{Zhu}$ YG. Chronic kidney disease of unknown etiology (CKDu): Using a system dynamics model to conceptualize the multiple environmental causative pathways of the epidemic. Sci Total Environ 2020;705:135766.

2. Abraham G, Agarwal SK, Gowrishankar S, et al. Chronic Kidney Disease of Unknown Etiology: Hotspots in India and Other Asian Countries. Semin Nephrol 2019;39:272-7.

3. Rajapakse S, Shivanthan MC, Selvarajah M. Chronic kidney disease of unknown etiology in Sri Lanka. Int J Occup Environ Health 2016;22:259-64.

4. Dharma-Wardana MWC. Chronic kidney disease of unknown etiology and the effect of multiple-ion interactions. Environ Geochem Health 2018;40:705-19.

5. Valcke M, Levasseur ME, Soares da Silva A, et al. Pesticide exposures and chronic kidney disease of unknown etiology: an epidemiologic review. Environ Health 2017;16:49.

6. Van Bruggen AHC, He MM, Shin K, et al. Environmental and health effects of the herbicide glyphosate. Sci Total Environ 2018;616-617:255-68.

7. Gillezeau C, van Gerwen M, Shaffer RM, et al. The evidence of human exposure to glyphosate: a review. Environ Health 2019;18:2.

8. Kwiatkowska M, Reszka E, Wo niak K, et al. DNA damage and methylation induced by glyphosate in human peripheral blood mononuclear cells (in vitro study). Food Chem Toxicol 2017;105:93-8.

9. Milić M, Žunec S, Micek V, et al. Oxidative stress, cholinesterase activity, and DNA damage in the liver, whole blood, and plasma of Wistar rats following a 28day exposure to glyphosate. Arh Hig Rada Toksikol 2018;69:154-68.

10. Mesnage R, Arno M, Costanzo M, et al. Transcriptome profile analysis reflects rat liver and kidney damage following chronic ultra-low dose Roundup exposure. Environ Health 2015;14:70.

11. Gao H, Chen J, Ding F, et al. Activation of the N-methyl$\mathrm{d}$-aspartate receptor is involved in glyphosate-induced renal proximal tubule cell apoptosis. J Appl Toxicol 2019;39:1096-107.

12. Varade AM, Yenkie R, Shende R, et al. Drinking Water Quality Assessment Studies for an Urbanized Part of the Nagpur District, Central India. J Environ Sci Eng 2014;56:53-64.

13. Ferrè $S$, Hoenderop JG, Bindels RJ. Sensing mechanisms involved in $\mathrm{Ca} 2+$ and $\mathrm{Mg} 2+$ homeostasis. Kidney Int 2012;82:1157-66.

14. Murakami M, Nakatani Y, Atsumi GI, et al. Regulatory Functions of Phospholipase A2. Crit Rev Immunol 2017;37:127-95.

15. Mouchlis VD, Dennis EA. Phospholipase A2 catalysis and lipid mediator lipidomics. Biochim Biophys Acta Mol Cell Biol Lipids 2019;1864:766-71.

16. Hirabayashi T, Murayama T, Shimizu T. Regulatory mechanism and physiological role of cytosolic phospholipase A2. Biol Pharm Bull 2004;27:1168-73.

17. Hsieh HL, Wu CY, Hwang TL, et al. BK-induced cytosolic phospholipase A2 expression via sequential PKCdelta, p42/p44 MAPK, and NF-kappaB activation in rat brain astrocytes. J Cell Physiol 2006;206:246-54.

18. Lupo G, Anfuso CD, Ragusa N, et al. Activation of cytosolic phospholipase A2 and 15-lipoxygenase by oxidized low-density lipoproteins in cultured human lung fibroblasts. Biochim Biophys Acta 2007;1771:522-32.

19. Leslie CC. Cytosolic phospholipase A2: physiological function and role in disease. J Lipid Res 2015;56:1386-402.

20. Rosengarten M, Hadad N, Solomonov Y, et al. Cytosolic phospholipase A2 $\alpha$ has a crucial role in the pathogenesis of DSS-induced colitis in mice. Eur J Immunol 2016;46:400-8.

21. Bhowmick R, Clark S, Bonventre JV, et al. Cytosolic Phospholipase A2 $\alpha$ Promotes Pulmonary Inflammation and Systemic Disease during Streptococcus pneumoniae Infection. Infect Immun 2017;85:e0280-17.

22. Chavez-Abiega S, Mos I, Centeno PP, et al. Sensing Extracellular Calcium - An Insight into the Structure and Function of the Calcium-Sensing Receptor (CaSR). Adv Exp Med Biol 2020;1131:1031-63.

23. Riccardi D, Valenti G. Localization and function of the renal calcium-sensing receptor. Nat Rev Nephrol 2016;12:414-25.

24. Pavicevic Z, Leslie CC, Malik KU. cPLA2 phosphorylation at serine- 515 and serine-505 is required for arachidonic 
acid release in vascular smooth muscle cells. J Lipid Res 2008;49:724-37.

25. Chang JF, Yeh JC, Ho CT, et al. Targeting ROS and cPLA2/COX2 Expressions Ameliorated Renal Damage in Obese Mice with Endotoxemia. Int J Mol Sci 2019;20:4393.

26. Chao CC, Gutiérrez-Vázquez C, Rothhammer V, et al. Metabolic Control of Astrocyte Pathogenic Activity via cPLA2-MAVS. Cell 2019;179:1483-1498.e22.

27. Lunyera J, Mohottige D, Von Isenburg M, et al. CKD of Uncertain Etiology: A Systematic Review. Clin J Am Soc Nephrol 2016;11:379-85.

28. Diyabalanage S, Fonseka S, Dasanayake DMSNB, et al. Environmental exposures of trace elements assessed using keratinized matrices from patients with chronic kidney diseases of uncertain etiology $(\mathrm{CKDu})$ in Sri Lanka. J Trace Elem Med Biol 2017;39:62-70.

29. Jayasumana C, Gunatilake S, Senanayake P. Glyphosate, hard water and nephrotoxic metals: are they the culprits behind the epidemic of chronic kidney disease of unknown etiology in Sri Lanka? Int J Environ Res Public Health 2014;11:2125-47.

30. Jayasumana C, Paranagama P, Agampodi S, et al. Drinking well water and occupational exposure to Herbicides is associated with chronic kidney disease, in Padavi-Sripura, Sri Lanka. Environ Health 2015;14:6.

31. Gunarathna S, Gunawardana B, Jayaweera M, et al. Glyphosate and AMPA of agricultural soil, surface water, groundwater and sediments in areas prevalent with chronic kidney disease of unknown etiology, Sri Lanka. J Environ Sci Health B 2018;53:729-37.

32. Wasana HM, Aluthpatabendi D, Kularatne WM, et al. Drinking water quality and chronic kidney disease of unknown etiology (CKDu): synergic effects of fluoride, cadmium and hardness of water. Environ Geochem Health 2016;38:157-68.

33. Perez-Gomez MV, Martin-Cleary C, FernandezFernandez B, et al. Meso-American nephropathy: what we have learned about the potential genetic influence on chronic kidney disease development. Clin Kidney J 2018;11:491-495.

34. Landrigan PJ, Belpoggi F. The need for independent research on the health effects of glyphosate-based herbicides. Environ Health 2018;17:51.

35. Mohamed F, Endre ZH, Pickering JW, et al. Mechanismspecific injury biomarkers predict nephrotoxicity early following glyphosate surfactant herbicide (GPSH) poisoning. Toxicol Lett 2016;258:1-10.
36. Wunnapuk K, Gobe G, Endre Z, et al. Use of a glyphosate-based herbicide-induced nephrotoxicity model to investigate a panel of kidney injury biomarkers. Toxicol Lett 2014;225:192-200.

37. Kulathunga MRDL, Ayanka Wijayawardena MA, Naidu $\mathrm{R}$, et al. Chronic kidney disease of unknown aetiology in Sri Lanka and the exposure to environmental chemicals: a review of literature. Environ Geochem Health 2019;41:2329-38.

38. Ranieri M. Renal $\mathrm{Ca} 2+$ and Water Handling in Response to Calcium Sensing Receptor Signaling: Physiopathological Aspects and Role of CaSR-Regulated microRNAs. Int J Mol Sci 2019;20:5341.

39. Hendy GN, Canaff L. Calcium-sensing receptor, proinflammatory cytokines and calcium homeostasis. Semin Cell Dev Biol 2016;49:37-43.

40. Smith KA, Ayon RJ, Tang H, et al. Calcium-Sensing Receptor Regulates Cytosolic [Ca2+] and Plays a Major Role in the Development of Pulmonary Hypertension. Front Physiol 2016;7:517.

41. Zhang C, Miller CL, Brown EM, et al. The calcium sensing receptor: from calcium sensing to signaling. Sci China Life Sci 2015;58:14-27.

42. Kang DR, Belal SA, Choe HS, et al. Effect of Kaempferol on Cyclooxygenase 2 (Cox2) and Cytosolic Phospholipase A2 (cPLA2) Protein Expression in BALB/c Mice. Iran J Allergy Asthma Immunol 2018;17:428-35.

43. Chuang DY, Simonyi A, Kotzbauer PT, et al. Cytosolic phospholipase A2 plays a crucial role in ROS/NO signaling during microglial activation through the lipoxygenase pathway. J Neuroinflammation 2015;12:199.

44. Basselin M, Chang L, Bell JM, et al. Chronic lithium chloride administration attenuates brain NMDA receptorinitiated signaling via arachidonic acid in unanesthetized rats. Neuropsychopharmacology 2006;31:1659-74.

45. Cho KJ, Seo JM, Kim JH. Bioactive lipoxygenase metabolites stimulation of NADPH oxidases and reactive oxygen species. Mol Cells 2011;32:1-5.

46. Ost M, Uhl E, Carlsson M, et al. Expression of mRNA for phospholipase A2, cyclooxygenases, and lipoxygenases in cultured human umbilical vascular endothelial and smooth muscle cells and in biopsies from umbilical arteries and veins. J Vasc Res 1998;35:150-5.

47. Wang T, Fu X, Chen Q, et al. Arachidonic Acid Metabolism and Kidney Inflammation. Int J Mol Sci 2019;20:3683.

48. Yang L, Liu Y, Lv W, et al. Expression of interferonstimulated gene $15-\mathrm{kDa}$ protein, cyclooxygenase (COX) 
1, COX-2, aldo-keto reductase family 1, member B1, and prostaglandin E synthase in the spleen during early pregnancy in sheep. Anim Sci J 2018;89:1540-8.

49. Yao C, Narumiya S. Prostaglandin-cytokine crosstalk in chronic inflammation. Br J Pharmacol 2019;176:337-54

50. Homaidan FR, Chakroun I, Haidar HA, et al. Protein regulators of eicosanoid synthesis: role in inflammation. Curr Protein Pept Sci 2002;3:467-84.

51. Ayoub SS, Wood EG, Hassan SU, et al. Cyclooxygenase expression and prostaglandin levels in central nervous system tissues during the course of chronic relapsing experimental autoimmune encephalomyelitis (EAE). Inflamm Res 2011;60:919-28.

52. Martínez-Colón GJ, Moore BB. Prostaglandin E2 as a Regulator of Immunity to Pathogens. Pharmacol Ther 2018;185:135-46.

53. Korbecki J, Baranowska-Bosiacka I, Gutowska I, et al. Cyclooxygenase pathways. Acta Biochim Pol 2014;61:639-49.

54. Erkan LG, Altinbas B, Guvenc G, et al. Brain thromboxane A2 via arachidonic acid cascade induces the hypothalamicpituitary-gonadal axis activation in rats. Auton Neurosci 2015;189:50-5.

55. Nakanishi M, Rosenberg DW. Multifaceted roles of PGE2 in inflammation and cancer. Semin Immunopathol 2013;35:123-37.

56. Li S, Andoh T, Zhang Q, et al. $\beta 2-$ Microglobulin, interleukin-31, and arachidonic acid metabolites (leukotriene B4 and thromboxane A2) are involved in chronic renal failure-associated itch-associated responses in mice. Eur J Pharmacol 2019;847:19-25.

57. Hegde B, Bodduluri SR, Satpathy SR, et al. Inflammasome-Independent Leukotriene B4 Production Drives Crystalline Silica-Induced Sterile Inflammation. J Immunol 2018;200:3556-67.

58. Sasaki F, Yokomizo T. The leukotriene receptors as therapeutic targets of inflammatory diseases. Int Immunol 2019;31:607-15.

59. Chalimoniuk M, Stolecka A, Ziemińska E, et al. Involvement of multiple protein kinases in cPLA2 phosphorylation, arachidonic acid release, and cell death in in vivo and in vitro models of 1-methyl-4phenylpyridinium-induced parkinsonism--the possible key role of PKG. J Neurochem 2009;110:307-17.

60. Rupprecht G, Scholz K, Beck KF, et al. Cross-talk between group IIA-phospholipase A2 and inducible NO-synthase in rat renal mesangial cells. Br J Pharmacol 1999;127:51-6.

61. Palomba L, Persichini T, Mazzone V, et al. Inhibition of nitric-oxide synthase-I (NOS-I)-dependent nitric oxide production by lipopolysaccharide plus interferon-gamma is mediated by arachidonic acid. Effects on NFkappaB activation and late inducible NOS expression. J Biol Chem 2004;279:29895-901.

62. Lin X, Bai D, Wei Z, et al. Curcumin attenuates oxidative stress in RAW264.7 cells by increasing the activity of antioxidant enzymes and activating the Nrf2-Keap1 pathway. PLoS One 2019;14:e0216711.

63. Goc Z, Szaroma W, Kapusta E, et al. Protective effects of melatonin on the activity of SOD, CAT, GSH-Px and GSH content in organs of mice after administration of SNP. Chin J Physiol 2017;60:1-10.

64. Chalimoniuk M. [Secretory phospholipase A2 and its role in oxidative stress and inflammation]. Postepy Biochem 2012;58:204-8.

65. Simonyi A, He Y, Sheng W, et al. Targeting NADPH oxidase and phospholipases A2 in Alzheimer's disease. Mol Neurobiol 2010;41:73-86.

66. Yuan J, Zhu C, Hong Y, et al. The role of cPLA2 in Methylglyoxal-induced cell apoptosis of HUVECs. Toxicol Appl Pharmacol 2017;323:44-52.

67. Wang QS, Shen SQ, Sun HW, et al. Interferon-gamma induces autophagy-associated apoptosis through induction of cPLA2-dependent mitochondrial ROS generation in colorectal cancer cells. Biochem Biophys Res Commun 2018;498:1058-65.

68. Rukoyatkina N, Mindukshev I, Walter U, et al. Dual role of the $\mathrm{p} 38 \mathrm{MAPK} / \mathrm{cPLA} 2$ pathway in the regulation of platelet apoptosis induced by ABT-737 and strong platelet agonists. Cell Death Dis 2013;4:e931.

69. Krishnan N, Perazella MA. Drug-induced acute interstitial nephritis: pathology, pathogenesis, and treatment. Iran J Kidney Dis 2015;9:3-13.

70. Liu Y. Cellular and molecular mechanisms of renal fibrosis. Nat Rev Nephrol 2011;7:684-96.

71. Montford JR, Lehman AM, Scobey MS, et al. Cytosolic phospholipase A2 $\alpha$ increases proliferation and dedifferentiation of human renal tubular epithelial cells. Prostaglandins Other Lipid Mediat 2016;126:1-8.

(English Language Editor: J. Teoh)

Cite this article as: Wang $\mathrm{R}$, Chen J, Ding $\mathrm{F}$, Zhang L, Wu X, Wan Y, Hu J, Zhang X, Wu Q. Renal tubular injury induced by glyphosate combined with hard water: the role of cytosolic phospholipase A2. Ann Transl Med 2021;9(2):130. doi: 10.21037/atm-20-7739 